\title{
MENGGALI NILAI-NILAI KEUNGGULAN LOKAL KESENIAN REOG PONOROGO GUNA MENGEMBANGKAN MATERI KERAGAMAN SUKU BANGSA DAN BUDAYA PADA MATA PELAJARAN IPS KELAS IV SEKOLAH DASAR
}

\author{
Imam Gunawan * \\ Rina Tri Sulistyoningrum **
}

\begin{abstract}
Value from a culture nation inheritance is very important. Local wisdom a region contains values necessary exploration and preserved. Reog is one of the artistry enough famous from region Ponorogo and known by world society. Values found in artistry Reog Ponorogo presumably necessary are exploration furthermore to can be ingredient for tribe unity matter development and culture in course social science class IV elementary school. With artistry local superiority values implementation existence Reog Ponorogo, supposed student realizes and apply values from region culture permanently respect coalitions taste and sense of belonging towards region culture. This research aims to detect artistry local superiority values Reog Ponorogo that is used to develop tribe unity matter and culture course elementary school. Research data collecting is done gradually that is passes documentation study, observation, and interview. Technique that done gradually (triangulating) this chosen to guarantee data validity. Data is fished from informant that chosen with snowball sampling technique. Taking manner sampling with this technique is done according to related to, sample determination technique at first number little, longer more expand. In first research at first is chosen one or two person but because data to felted not yet enough so researcher looks for another person that can equip data that got from previous person. These research results show that artistry local superiority values Reog Ponorogo can be used to develop tribe unity matter and subject culture social science Class IV elementary school that is: leadership, aesthetics, and agreement.
\end{abstract}

Keyword: Local Wisdom, Artistry Reog Ponorogo, Tribe Unity and Culture

\begin{abstract}
Abstrak
Nilai dari suatu kebudayaan adalah warisan bangsa yang sangat berharga. Unggulan lokal suatu daerah mengandung nilai-nilai yang
\end{abstract}

* Imam Gunawan adalah Dosen Program Studi PGSD FIP IKIP PGRI Madiun

** Rina Tri Sulistyoningrum adalah Mahasiswa Program Studi PGSD FIP IKIP PGRI Madiun 
perlu digali dan dilestarikan. Reog adalah salah satu kesenian yang cukup terkenal dari daerah Ponorogo dan telah dikenal oleh masyarakat dunia. Nilai-nilai yang terdapat dalam kesenian Reog Ponorogo kiranya perlu digali lebih lanjut untuk dapat menjadi bahan bagi pengembangan materi keragaman suku bangsa dan budaya pada matapelajaran Ilmu Pengetahuan Sosial Kelas IV sekolah dasar. Dengan adanya implementasi nilai-nilai keunggulan lokal kesenian Reog Ponorogo, diharapkan siswa memahami dan mengamalkan nilai-nilai dari budaya daerah dengan tetap menjunjung tinggi rasa persatuan dan rasa memiliki terhadap budaya daerah. Penelitian ini bertujuan untuk mengetahui nilai-nilai keunggulan lokal kesenian Reog Ponorogo yang digunakan untuk mengembangkan materi keragaman suku bangsa dan budaya matapelajaran sekolah dasar. Pengumpulan data penelitian dilakukan secara bertahap yaitu melalui studi dokumentasi, observasi, dan wawancara. Teknik yang dilakukan secara bertahap (triangulasi) ini dipilih untuk menjamin keabsahan data yang akan diperoleh. Data dijaring dari informan yang dipilih dengan snowball sampling technique. Cara pengambilan sampling dengan teknik ini dilakukan secara berantai, teknik penentuan sampel yang mula-mula berjumlah kecil, semakin lama semakin membesar. Dalam penelitian pertama mula-mula dipilih satu atau dua orang tetapi karena data yang didapat dirasa belum cukup maka peneliti mencari orang lain yang dapat melengkapi data yang didapat dari orang sebelumnya. Hasil penelitian ini menunjukkan bahwa nilainilai keunggulan lokal kesenian Reog Ponorogo dapat digunakan untuk mengembangkan materi keragaman suku bangsa dan budaya mata pelajaran IPS Kelas IV sekolah dasar, yakni adalah: kepemimpinan, estetika, dan kerjasama.

\section{Kata Kunci: Keunggulan Lokal, Kesenian Reog Ponorogo, Keragaman Suku Bangsa dan Budaya}

\section{A. PENDAHULUAN}

Nilai merupakan sesuatu yang abstrak, namun hal tersebut menjadi pedoman bagi kehidupan masyarakat. Suyatno (2008: 24) berpendapat bahwa nilai adalah kemampuan yang dipercayai ada pada suatu benda untuk memuaskan manusia. Nilai adalah ukuran yang sangat penting dalam kehidupan manusia sebagai pedoman setiap tingkah laku manusia sebagai makhluk sosial. Kebudayaan maupun kesenian mengandung nilai-nilai yang sangat penting bagi kehidupan masyarakat. Negara yang maju adalah negara yang dapat menyeimbangkan kemajuan teknologi dengan tetap mempertahankan nilai budayanya. Negara yang maju adalah negara yang berdiri kokoh dengan sumber daya, kekayaan alam, dan keberagaman budayanya, sehingga mengakar kuat dengan kemandirian dan kepercayaan dirinya. Untuk menjadi negara yang maju, suatu negara harus mempunyai keseriusan untuk mengembangkan potensi atau keunggulan lokalnya. Potensi-potensi yang ada pada setiap daerah harus dikembangkan sesuai dengan kondisi masing-masing daerah. 
Ketika pemerintahan berjalan dengan sistem sentralistik, Barat menjadi kiblat dengan memarginalkan kekayaan potensi lokal yang semestinya dikembangkan sebagai produk unggulan yang memegang peran penting dan sesuai dengan tradisi masyarakat. Namun perubahan yang terjadi saat ini sangat berpengaruh besar terhadap semua aspek kehidupan bangsa Indonesia karena adanya perubahan politik dan tata pemerintahan yang semula bersifat sentralistik menjadi desentralistik. Salah satunya adalah desentralistik dalam bidang pendidikan. Saat ini fungsi dan wewenang pemerintah daerah lebih besar dalam membuat kebijakan dan melaksanakannya sesuai dengan variasi potensi dan kepentingan pengembangan daerahnya masing-masing. Karena kondisi dan potensi daerah di Indonesia yang cukup beragam maka daerah perlu menggali, meningkatkan dan mempromosikan potensinya melalui pendidikan di sekolah (Asmani, 2012: 20). Guru sebagai pelaku pendidikan dapat mengembangkan dan menggali keunggulan lokal dengan cara mengaitkannya dengan materi mata pelajaran yang sesuai.

Keunggulan lokal adalah suatu proses dan realisasi peningkatan nilai dari suatu potensi daerah sehingga menjadi produk atau jasa atau karya lain yang bernilai tinggi, bersifat unik dan memiliki keunggulan komparatif (Asmani, 2012: 54). Keunggulan lokal yang dimiliki masing-masing daerah sangat bervariasi. Dengan keberagaman potensi daerah, pengembangan potensi dan keunggulan daerah perlu mendapatkan perhatian secara khusus bagi pemerintah daerah agar anak-anak daerah tidak asing dengan daerahnya sendiri dan paham betul tentang potensi dan nilai-nilai, serta budaya daerahnya sendiri. Salah satu unggulan lokal dari daerah Ponorogo adalah kesenian Reog Ponorogo. Reog adalah salah satu keseniaan terkenal dari Indonesia yang sampai sekarang masih aktif dan dikenal oleh seluruh masyarakat Indonesia bahkan wisatawan mancanegara. Pemerintah kabupaten Ponorogo telah mendaftarkan kesenian Reog Ponorogo sebagai hak cipta milik Kabupaten Ponorogo. Tercatat dengan Nomor 026377 tanggal 11 Februari 2004 dan diketahui langsung oleh Menteri Hukum dan Hak Asasi Manusia Republik Indonesia, mengingat akan keprihatinan seluruh elemen masyarakat Indonesia akan diakuinya beberapa kesenian asli bangsa Indonesia oleh bangsa lain. Nilai-nilai yang terdapat dalam kesenian Reog Ponorogo kiranya perlu digali lebih lanjut untuk dapat menjadi bahan bagi pengembangan materi pada matapelajaran Ilmu Pengetahuan Sosial (IPS).

IPS adalah matapelajaran yang mempelajari kehidupan sosial yang kajiannya mengintegrasikan bidang ilmu-ilmu sosial dan humaniora (Sumaatmadja, 2008: 19). Pengetahuan sosial memang dapat diperoleh dalam kehidupan sehari-hari, namun pengetahuan sosial yang diperoleh secara alamiah itu saja tidak cukup oleh karena itu pendidikan formal khususnya pendidikan IPS di sekolah menjadi tuntutan yang tidak dapat diabaikan. Pendidikan IPS bertujuan untuk membina anak didik menjadi warga negara yang baik, yang memiliki pengetahuan, keterampilan dan kepedulian sosial yang berguna bagi dirinya sendiri serta bagi masyarakat dan negara. IPS sebagai pendidikan bukan hanya semata-mata membekali anak didik dengan pengetahuan yang membebani mereka, melainkan membekali mereka dengan pengetahuan sosial yang berguna yang dapat diterapkan dalam kehidupan mereka sehari-hari (Sumaatmadja, 2008: 19). 
Karena IPS mempelajari tentang kehidupan sosial maka IPS tidak lepas dari nilai-nilai dan kehidupan dalam masyarakat. Terutama nilai-nilai yang terdapat dalam keunggulan lokal kesenian Reog Ponorogo. Nilai-nilai yang terdapat dalam kesenian Reog Ponorogo perlu digali agar dapat diimplementasikan ke dalam materi pelajaran sehingga nilai-nilai tersebut akan menginspirasi setiap tingkah laku siswa juga sebagai bekal bagi kehidupannya sehari-hari. Kenyataan yang nampak sekarang adalah kurangnya kesadaran generasi muda akan adanya nilai-nilai dari suatu kesenian dan kebudayaan setempat. Nilai dari suatu kesenian dan kebudayaan adalah warisan bangsa yang sangat berharga. Nilai-nilai yang terkandung dalam suatu kesenian maupun kebudayaan tidak akan muncul dengan sendirinya jika kita tidak berusaha untuk mengungkapnya sejalan dengan banyaknya kebudayaan asing yang masuk ke Indonesia.

\section{B. KAJIAN PUSTAKA \\ 1. Konsep Nilai}

Manusia memiliki nilai yang dianut dan diyakini berdasarkan perasaannya sendiri yang bersifat subjektif. Nilai ini dinamakan sebagai nilai individual. Sedangkan nilai-nilai yang dianut oleh manusia secara masal di masyarakat yang didasarkan pada pandangan dan ukuran orang banyak dinamakan dengan nilai sosial. Setiap masyarakat memiliki pedoman atau patokan yang membatasi tingkah laku mereka. Nilai yang dimiliki antara satu masyarakat dengan masyarakat lainnya berbeda, hal tersebut dikarenakan setiap orang memiliki pandangan berbeda terhadap suatu hal. Nilai digunakan sebagai acuan bagaimana seseorang harus bertingkah laku sehingga ia tidak dikatakan sebagai orang yang menyimpang dalam komunitasnya. Nilai adalah kualitas dari sesuatu yang bermanfaat bagi kehidupan manusia, baik lahir maupun batin. Nilai bersifat abstrak, hanya dapat dipahami, dipikirkan, dimengerti dan dihayati oleh manusia (Nurcahyo, dkk., 2011: 102). Sedangkan menurut Djahiri nilai (value) adalah harga, makna, isi dan pesan, semangat atau jiwa yang tersurat dan tersirat dalam fakta, konsep dan teori sehingga bermakna secara fungsional (Nurcahyo, dkk., 2011: 102).

Sementara itu Suyatno (2008: 24) menjelaskan nilai adalah kemampuan yang dipercayai yang ada pada suatu benda untuk memuaskan manusia. Sesuatu dikatakan bernilai apabila sesuatu itu berharga, berguna, benar, indah, baik, dan lain sebagainya. Hal senada dikemukakan oleh Asmani (2012: 99) yang berpendapat nilai adalah suatu standar perilaku yang telah diyakini dan secara psikologis telah menyatu dalam diri seseorang, misalnya standar perilaku guru dalam pembelajaran. Nilai menjadi batasan pembeda antara yang baik dan yang buruk, yang benar dan salah atau yang pantas dan tidak pantas. Nilai adalah hal yang bersifat mendasar, dan nilai yang diyakini setiap orang berbeda-beda sesuai dengan apa yang telah diyakini sekelompok orang atau masyarakat. Nilai mempunyai fungsi bagi setiap orang maupun masyarakat, dengan adanya nilai akan muncul suatu konsep atau teori yang kemudian mereka yakini. Sehingga dapat disimpulkan bahwa nilai adalah suatu konsep benar salah dan baik buruknya perilaku manusia. Pada umumnya nilai dibagi menjadi tiga macam, yaitu: (1) nilai material, yaitu segala sesuatu yang berguna bagi kehidupan jasmani manusia atau kebutuhan material ragawi manusia; (2) nilai vital, yaitu segala sesuatu yang 
berguna bagi manusia untuk dapat mengadakan kegiatan atau aktivitas; dan (3) nilai kerohanian, yaitu segala sesuatu yang berguna bagi rohani manusia. Nilai kerohanian dapat dibedakan atas 4 macam, yaitu: nilai kebenaran; nilai keindahan; nilai kebaikan; dan nilai religius.

Menurut Suyatno (2008: 24-25) nilai dibagi menjadi tiga macam, yaitu nilai dasar, nilai instrumental, dan nilai praktis. Nilai dasar (antologis) merupakan hakekat, esensi, intisari atau makna yang terkandung dalam nilai-nilai tersebut yang bersifat universal yang mengakui hakekat Tuhan dan manusia. Nilai instumental merupakan nilai sebagai pedoman untuk dapat merealisasikan nilai dasar dimana harus memiliki formulasi atau parameter atau ukuran yang jelas. Nilai instrumental inilah yang merupakan suatu pedoman yang dapat diukur dan diarahkan, contohnya nilai instrumental yang berkaitan dengan tingkah laku manusia adalah suatu nilai moral sedangkan nilai instrumental yang berkaitan dengan suatu organisasi manusia adalah suatu arahan, kebijaksanaan strategis. Nilai praktis pada hakikatnya merupakan penjabaran lebih lanjut dari nilai instrumental dalam suatu kehidupan yang nyata sehingga suatu nilai praktis merupakan perwujudan dari nilai instrumental.

\section{Keunggulan Lokal}

Keunggulan lokal merupakan ciri khas suatu daerah baik berupa budaya, keadaan alam, maupun ciri khas yang lainnya. Salah satu contoh keunggulan lokal adalah telaga Sarangan di Kabuten Magetan yang keberadaannya telah diketahui oleh masyarakat lokal hingga wisatawan mancanegara. Telaga Sarangan menjadi salah satu keunggulan lokal Kabupaten Magetan karena selain memiliki keindahan alam, keberadaan telaga tersebut juga menjadi sumber pendapatan masyarakat setempat yang sebagian besar bermata pencaharian sebagai pedagang di sekitar telaga. Karena itulah telaga Sarangan dapat disebut sebagai keunggulan lokal. Dwitagama berpendapat bahwa keunggulan lokal adalah segala sesuatu yang menjadi ciri khas kedaerahan yang mencakup aspek ekonomi, budaya, teknologi informasi, komunikasi, dan ekologi (Asmani, 2012: 29). Keunggulan lokal ialah hasil bumi, kreasi seni, tradisi, budaya, pelayanan, jasa, sumber daya alam, sumber daya manusia, atau lainnya yang menjadi keunggulan suatu daerah.

Keunggulan lokal merupakan suatu proses dan realisasi peningkatan nilai dari suatu potensi daerah sehingga menjadi produk atau jasa atau karya lain yang bernilai tinggi, bersifat unik, dan memiliki keunggulan komparatif. Contohnya: olahraga, kesenian, pertanian (Asmani, 2012: 54). Kondisi alam dan keberagaman kebudayaan bangsa Indonesia menyebabkan masing-masing daerah di Indonesia memiliki keunggulan yang berbeda dengan daerah lain. Masing-masing daerah mempunyai kewajiban untuk mengembangkan potensinya. Sudrajat menyatakan bahwa konsep pengembangan keunggulan lokal diinspirasi dari berbagai potensi, yaitu potensi sumber daya alam (SDA), sumber daya manusia (SDM), geografis, budaya, dan historis (Asmani, 2012: 32). Untuk mengembangkan keunggulan lokal, potensi-potensi tersebut harus dikelola dengan baik. Potensi-potensi tersebut dijelaskan sebagai berikut:

a. Potensi Sumber Daya Alam

Sumber daya alam adalah potensi yang terkandung dalam bumi, air, dan dirgantara yang dapat didayagunakan untuk berbagai kepentingan hidup. Contoh bidang pertanian ialah padi, jagung, buah-buahan, sayuran, dan lain sebagainya; 
bidang perkebunan seperti karet, tebu, tembakau, sawit, cokelat dan lain-lain; bidang peternakan misalnya unggas, kambing, sapi, dan lain sebagainya; bidang perikanan seperti ikan alut dan tawar, rumput laut, tambak, dan lain-lain. Contoh lainnya misalnya di provinsi Jawa Timur memiliki keunggulan komparatif dan keragaman komoditas hortikultura buah-buahan yang spesifik, dengan jumlah lokasi ribuan hektar yang hampir tersebar diseluruh wilayah kabupaten atau kota. Keunggulan lokal ini akan lebih cepat berkembang, jika dikaitkan dengan konsep pembangunan agropolitan.

b. Potensi Sumber Daya Manusia

Sumber daya manusia merupakan penentu semua potensi keunggulan lokal. SDM sebagi sumber daya bisa bermakna positif dan negatif, tergantung pada paradigma, kultur dan etos kerja. Dengan kata lain tidak ada realisasi dan implementasi konsep keunggulan lokal tanpa melibatkan dan memposisikan manusia dalam proses pencapaian keunggulan. SDM sangat mempengaruhi kualitas dan kuantitas SDA, mencirikan identitas budaya, mewarnai sebaran geografis, dan dapat berpengaruh secara timbal balik kepada kondisi geologi, hidrologi dan klimatologi setempat akibat pilihan aktivitasnya, serta memiliki latar sejarah tertentu yang khas. Pada masa awal peradaban saat manusia masih amat tergantung pada alam, ketergantungannya yang besar terhadap air telah menyebabkan munculnya peradaban pertama di sekitar aliran sungai besar yang subur.

c. Potensi Geografis

Objek geografi meliputi objek formal dan material. Objek formal geografi adalah fenomena geosfer yang terdiri atas atmosfer bumi, cuaca dan iklim, litosfer, hidrosfer, biosfer (lapisan kehidupan fauna dan flora), serta antroposfer (lapisan manusia yang merupakan tema sentral). Namun tidak semua objek dan fenomena geografi berkaitan dengan konsep keunggulan lokal, karena keunggulan lokal hanya dicirikan oleh nilai guna fenomena geografis bagi kehidupan dan penghidupan yang memiliki dampak ekonomis, yang pada akhirnya berdampak pada kesejahteraan masyarakat. Potensi geografis yang mendukung jika dimanfaatkan dengan baik akan membawa kesejahteraan yang besar pada masyarakat.

d. Potensi Budaya

Budaya adalah sikap, sedangkan sumber sikap adalah kebudayaan. Agar kebudayaan dilandasi dengan sikap baik masyarakat perlu memadukan antara idealisme dengan realisme, yang pada hakikatnya merupakan perpaduan antara seni dan budaya. Ciri-ciri budaya masing-masing daerah tertentu (yang berbeda dengan daerah lain) merupakan sikap menghargai kebudayaan daerah sehingga menjadi keunggulan lokal. beberapa contoh menghargai kebudayaan setempat, yaitu upacara Ngaben di Bali, Sekatenan di Yogyakarta dan Solo, serta upacara adat perkawinan di berbagai daerah. Sebagai ilustrasi keunggulan lokal yang diinspirasi oleh budaya, misalnya di Kabupaten Jombang Jawa Timur, telah dikenal beberapa karya, antara lain: (1) Teater Tombo Ati (Emha Ainun Najib); (2) Musik Albanjari (hadrah); (3) Kesenian Ludruk Besutan; dan (4) Ritualisasi Wisuda Sinden (Sendang Beji).

e. Potensi Historis

Keunggulan lokal dalam konsep historis merupakan potensi sejarah dalam bentuk peninggalan benda-benda purbakala maupun tradisi yang masih 
dilestarikan hingga saat ini. Konsep historis jika dioptimalkan pengelolaannya bisa menjadi tujuan wisata yang dapat menjadi aset, bahkan menjadi keunggulan lokal dari suatu daerah tertentu. Pada potensi ini diperlukan akulturasi terhadap nilai-nilai tradisional dengan memberi kultural baru agar terjadi perpaduan antara kepentingan tradisional dan kepentingan modern, sehingga aset atau potensi sejarah bisa menjadi aset atau potensi keunggulan lokal. Salah satu contoh keunggulan lokal yang di inspirasi oleh potensi sejarah adalah tentang kebesaran Kerajaan Majapahit. Pemerintah Kabupaten Mojokerto secara rutin menyelenggarakan perkawinan ala Majapahit sebagai acara resmi yang disosialisasikan kepada masyarakat.

\section{Pendidikan Berbasis Keunggulan Lokal}

Pendidikan yang bersifat sentralistik telah membuktikan potensi yang dimiliki masing-masing sekolah tidak dapat tumbuh optimal. Sedangkan keberhasilan sekolah tidak dapat lepas dari keberadaan lingkungan sekitar. Dengan adanya desentralisasi pendidikan daerah atau sekolah mempunyai wewenang penuh untuk memprogram dan mengembangkan pembelajaran sesuai dengan kebutuhan dan kondisi lingkungan sekitar. Karena keberagaman potensi dan keunggulan lokal pada setiap daerah maka daerah perlu menggali, meningkatkan dan mempromosikan potensinya melalui pendidikan di sekolah yang berbasis keunggulan lokal. Dwitagama menyebutkan pendidikan berbasis keunggulan lokal adalah pendidikan yang memanfaatkan keunggulan lokal dalam aspek ekonomi, budaya, bahasa, teknologi informasi dan komunikasi, ekologi dan lain-lain yang semuanya bermanfaat bagi pengembangan kompetensi peserta didik (Asmani, 2012: 29).

a. Tujuan Pendidikan Berbasis Keunggulan Lokal

Setiap hal yang telah dirancang atau ditetapkan tentunya memiliki tujuan masing-masing. Demikian halnya dengan pendidikan berbasis keunggulan lokal, tujuan penyelenggaran pendidikan berbasis keunggulan lokal adalah agar siswa mengetahui keunggulan lokal daerah tempat mereka tinggal, memahami berbagai aspek yang berhubungan dengan keunggulan lokal tersebut (Asmani, 2012: 41). Pendidikan berbasis keunggulan lokal akan memotivasi peserta didik untuk lebih mencintai dan memahami apa yang menjadi keunggulan lokal di daerahnya dan berusaha mengembangkannya. Mengingat kurangnya kepedulian generasi muda akan potensi daerahnya yang kadang dianggap tidak terlalu menguntungkan maka diharapkan dengan adanya pendidikan berbasis keunggulan lokal ini akan menumbuhkan cita-cita dan semangat generasi muda untuk mengembangkan potensi lokal sehingga daerahnya dapat berkembang pesat seiring dengan tuntutan era globalisasi dan informasi.

b. Landasan Pendidikan Berbasis Keunggulan Lokal

Asmani (2012: 42-43) menyebutkan ada beberapa hal yang menjadi landasan pendidikan berbasis keunggulan lokal, yaitu: (1) Undang-undang Nomor 22 Tahun 1999 tentang Pemerintah Daerah, menuntut pelaksanaan otonomi daerah dan wawasan demokrasi dalam penyelenggaraan pendidikan; (2) PP Nomor 25 Tahun 2000 tentang Kewenangan Pemerintah dan Kewenangan Provinsi sebagai daerah otonomi dalam bidang pendidikan; (3) Undang-undang Nomor 20 Tahun 2003 Bab XIV pasal 50 ayat 5 menegaskan bahwa pemerintah kabupaten / kota mengelola pendidikan dasar dan menengah, serta satuan 
pendidikan yang berbasis pendidikan lokal; dan (4) PP Nomor 19 Tahun 2005 Bab III pasal 14 ayat 1 menyatakan bahwa kurikulum untuk SMP / MTs / SMPLB atau bentuk lain yang sederajat, dapat memasukkan pendidikan berbasis keunggulan lokal.

Berdasarkan peraturan perundang-undangan tersebut sudah diatur bahwa pelaksanaan pendidikan di luar kewenangan pemerintah pusat, dan harus dilakukan di daerah (Asmani, 2012: 43). Kebijakan ini mempermudah pemerintah daerah untuk mengembangkan potensi daerahnya, yang harus disesuaikan dengan kebutuhan siswa, keadaan sekolah dan kondisi daerah. Adanya analisis yang perencanaan yang tepat sangat mempengaruhi keberhasilan pendidikan berbasis keunggulan lokal.

c. Ruang Lingkup Pendidikan Berbasis Keunggulan Lokal

Asmani (2012: 44-45) menyebutkan ruang lingkup pendidikan berbasis keunggulan lokal, yaitu: (1) lingkup situasi dan kondisi daerah yaitu segala sesuatu yang terdapat di daerah tersebut, yang berkaitan dengan lingkungan alam, sosial, ekonomi, seni, dan budaya atau lainnya yang berupa hasil bumi, tradisi, pelayanan / jasa, atau lainnya yang menjadi keunggulan daerah; dan (2) lingkup keunggulan lokal meliputi potensi keunggulan lokal, cara mengelola, mengolah atau mengemas, mengoptimalkan, memasarkan atau proses lainnya yang mampu menghasilkan nilai tambah bagi daerah sehingga dapat meningkatkan taraf hidup atau kesejahteraan maupun pendapatan asli daerah. Ruang lingkup tersebut menuntut sekolah untuk melakukan analisis secara mendalam mengenai potensi daerah yang akan dikembangkan di sekolah ditinjau dari berbagai segi formal maupun non formal. Analisis yang tepat sasaran sangat signifikan dalam formulasi pendidikan berbasis keunggulan lokal.

d. Strategi Implementasi Pendidikan Berbasis Keunggulan Lokal

Pendidikan berbasis keunggulan lokal merupakan program baru dalam dunia pendidikan. Banyak lembaga pendidikan yang belum memahami implementasi pendidikan berbasis keunggulan lokal di lapangan. Jika dikaitkan dengan kebutuhan daerah dan sekolah pendidikan berbasis keunggulan lokal sebenarnya sangat berpengaruh terhadap masa depan peserta didik dan kemajuan daerah, sehingga pendidikan berbasis keunggulan lokal perlu dirancang dan dilaksanakan oleh masing-masing sekolah. Mursal menyebutkan beberapa langkah yang harus dilakukan untuk implementasi pendidikan berbasis keunggulan lokal (Asmani, 2012 62-63), yaitu: (1) tahap inventarisasi keunggulan lokal; (2) tahap analisis kesiapan satuan pendidikan; (3) tahap penentuan tema dan jenis keunggulan lokal; dan (4) tahap implementasi lapangan.

Tahap inventarisasi keunggulan lokal dilakukan untuk mengidentifikasi seluruh keunggulan lokal yang ada di daerah. Keunggulan lokal diinventarisasi dari setiap aspek sumber daya manusia, sumber daya alam, geografis, sejarah, dan budaya yang dapat dilakukan melalui teknik observasi, wawancara, atau studi literatur. Pada tahap analisis kesiapan satuan pendidikan, pendidik atau tim yang ditugaskan sekolah menganalisis semua kelebihan atau keunggulan internal dan eksternal satuan pendidikan yang dilihat dari berbagai aspek dengan cara mengelompokkan keunggulan yang saling berkaitan satu sama lain. Tahap penentuan tema dan jenis keunggulan lokal, mempertimbangkan tiga hal, yaitu: (1) hasil inventarisasi potensi keunggulan lokal yang dihasilkan, dipilih keunggulan lokal yang bernilai komparatif dan kompetitif; (2) hasil analisis 
internal dan eksternal satuan pendidikan; dan (3) minat dan bakat peserta didik. Selanjutnya tahap implementasi lapangan harus disesuaikan dengan kemampuan masing-masing satuan pendidikan, mengacu pada hasil analisis faktor eksternal dan internal, hasil inventarisasi potensi keunggulan lokal, minat, serta bakat peserta didik.

\section{Kesenian}

Seni mempunyai padanan kata: techne (Yunani), ars (Latin), kuns (Jerman), dan art (Inggris). Semuanya memiliki arti yang sama yaitu keterampilan dan kemampuan. Keterampilan dan kemampuan ini kemudian dikaitkan dengan tujuan seni misalnya nilai estetis (keindahan) etis dan nilai praktis. Namun seni sering dikaitkan dengan nilai estetis sehingga ada pendapat bahwa seni sama dengan keindahan. Husiman berpendapat bahwa seni adalah mencipta dalam arti luas (Sulistyo, 2005: 1). Mencipta dalam kegiatan seni mempunyai tiga sasaran utama yaitu: (1) nilai filosofis (perangai dasar, nilai psikologik) sasarannya adalah aktivitas menghayati seni; (2) nilai psikologik sasarannya ialah aktivitas menghayati dan mencipta serta telaah tentang seni; dan mempunyai sasaran yang berkaitan dengan fungsi sosial seni.

Sudarso berpendapat bahwa seni adalah segala macam keindahan ciptaan manusia. Lain halnya dengan pendapat Ki Hajar Dewantara yang menyatakan bahwa seni yaitu segala perbuatan manusia yang timbul dari perasaan hidupnya dan bersifat indah hingga dapat menggerakkan jiwa perasaan manusia. Sedangkan pengertian seni menurut Sujoko adalah kemahiran membuat atau melakukan sesuatu yang dipakai atau dimaksudkan sebagai perangsang pengalaman estetik yang memuaskan (Sulistyo, 2005: 2-3). Seni adalah ekspresi atas perasaan yang ingin disampaikan oleh seseorang yang kemudian akan menjadi bentuk karya seni. Misalnya berupa coretan di atas kanvas, nyanyian, tarian dan sebagainya yang mana kegiatan tersebut pada dasarnya berasal dari ide-ide maupun perasaan sehingga dapat dikatakan sebagai ekspresi seni.

Ekspresi seni merupakan ekspresi diri seseorang, dalam ekspresi diri manusia terdapat ekspresi khusus yang disebut kesenian. Dengan kesenian manusia mengekspresikan gagasan estetik atau pengalaman estetik. Kesenian merupakan penjelmaan pengalaman estetik untuk mewujudkan manusia dewasa yang sadar akan arti pentingnya berbudaya agar tidak kehilangan jati diri dan akal sehat. Ada tiga fungsi penting dalam penciptaan karya seni yaitu: (1) fungsi personal seni; (2) fungsi sosial seni; dan (3) fungsi fisik seni.

a. Fungsi Personal Seni

Pada bagian pengertian seni, telah dijelaskan bahwa karya seni adalah hasil ciptaan seniman. Dalam penciptaan karya itulah seniman merasakan kepuasan dalam pengungkapan atau penyaluran ekspresi personalnya. Meskipun ada sebagian kecil seniman tidak atau kurang merasakan kepuasan dalam berekspresi, misalnya ia melayani permintaan dari pemesan yang hasilnya sudah ditetapkan oleh pemesannya.

b. Fungsi Sosial Seni

Selama karya seni itu dicipta kemudian disuguhkan atau dipamerkan kepada orang lain maka dari situlah fungsi sosial seni akan hadir. Dalam hal ini kehadiran seni haruslah dapat dinikmati oleh banyak orang. Sebagai contoh karya seni yang berwujud patung kepahlawanan, hadirnya karya yang ditempatkan 
ditempat-tempat strategis ini mempunyai nilai sosial seni yang baik karena dapat menggugah perasaan orang atau memberikan semangat kebangsaan yang tinggi. Terciptanya fungsi sosial seni oleh karena: (1) ada kecenderungan mempengaruhi perilaku kolektif; (2) penciptaannya diutamakan untuk diperlihatkan atau dipergunakan dalam situasi publik; dan (3) mengekspresikan atau menggambarkan aspek-aspek sosial atau kelompok.

c. Fungsi Fisik Seni

Telaah fungsi fisik seni, yang paling tepat adalah pada hasil karya seni rupa. Sebab lewat hasil karya ini fungsi fisik seni akan dapat diwujudkan. Seni rupa yang berwujud benda dapat beroperasi sebagai tempat (wadah) dan alat. Seni rupa yang mempunyai fungsi fisik seni sebagai tempat, misalnya karya-karya arsitektur (rumah sebagai tempat tinggal manusia), atau misalnya almari berukir, nilai keindahannya tetap ada juga, almari tersebut mempunyai fungsi fisik seni sebagai tempat menyimpan makanan, buku, dan sebagainya.

Sahman menyebutkan bahwa ada dua tujuan yang melatarbelakangi kehadiran karya seni yakni tujuan praktis dan tujuan teoritik (Sulistyo, 2005: 4). Tujuan yang praktis berhubungan erat dengan kegunaan (applied art), meskipun tujuan praktis dan kegunaan keduanya dapat dibedakan. Manusia menggunakan benda-benda pakai secara otomatis menunjukkan kegunaannya. Untuk memberikan contoh konkret tujuan praktis ini antara lain dalam bidang arsitektur (pembangunan rumah) manusia mengenyam tujuan praktis dari karya seni ini yakni sebagai tempat berteduh dari sengatan sinar matahari dan waktu turun hujan. Desain-desain dalam seni kria lebih banyak memiliki tujuan praktis daripada tujuan teoritiknya. Tujuan teoritik adalah tujuan penciptaan karya seni yang tidak berhubungan dengan kegunaan, melainkan lebih pada kualitas. Seni yang mempunyai tujuan teoritik lebih sering disebut seni murni (fine art). Seni murni dapat berupa patung, dan lukisan. Seiring kemajuan jaman desain-desain kria kini banyak yang berubah fungsi menjadi benda bernilai seni, misalnya benda-benda hias. Perubahan fungsi seni yang seperti menimbulkan dampak yang baik, seniman bebas berkreasi tanpa harus berpedoman pada kegunaan hasil karyanya, melainkan terfokus pada kualitasnya. sifat-sifat seni adalah: audio (auditif); visual (yang tampak, yang berwujud); dan audio-visual.

Audio (auditif) adalah karya seni yang dapat kita dengar. Penghayatannya memerlukan indera pendengaran. Salah satu contohnya adalah seni musik (suara). Selain itu seni drama juga dapat digolongkan ke dalam seni yang bersifat auditif jika seni tersebut direkam dan diperdengarkan melalui radio. Visual (yang tampak, yang berwujud) adalah karya seni yang pengamatannya membutuhkan indera penglihatan. Karya seni tersebut mempunyai wujud yang konkret, sehingga dapat dilihat dan diraba bila diperlukan. Hasil karya seni yang bersifat visual yaitu karya seni rupa, baik berukuran dwimatra maupun trimatra. Salah satu contoh karya seni yang berukuran dwimatra adalah lukisan, dan saluh satu contoh trimatra adalah patung. Audio-visual adalah gabungan dari karya seni yang dapat dilihat dan didengar. Misalnya adalah film dan drama, selain kita melihat jalannya cerita kita juga dapat mendengarkan suara tokoh maupun musik pengiringnya. Sehingga pada karya seni ini selain kita dapat melihat dan mendengarkan tentunya kita membutuhkan peragaan atau demonstrasi dari karya seni tersebut. 
Saat ini berbagai macam seni telah tumbuh dan berkembang pada seluruh lapisan masyarakat, jika kita mau mengamati kita akan memperoleh pengetahuan mengenai bermacam-macam kesenian. Kesenian pada setiap daerah berbeda-beda. Hal tersebut dikarenakan perbedaan masyarakat dari segi geografis, historis, dan sebagainya. Kesenian dinikmati oleh masyarakat sebagai hiburan dan warisan dari nenek moyang. Dari sekian banyak jenis kesenian yang ada pada masyarakat, seni dapat digolongkan menjadi: seni rupa, seni musik, seni drama, dan seni tari.

a. Seni Rupa

Secara singkat dapat dikatakan bahwa seni rupa adalah karya seni yang memiliki wujud atau rupa. Artinya karya seni tersebut dapat kita lihat dengan mata. Pengertian seni rupa secara lengkap adalah gejala manifestasi batin dan pengalaman estetis dengan media garis, warna, tekstur, volume, ruang, dan sebagainya. Seni rupa biasanya diwujudkan dalam bentuk seni lukis. Seni rupa dapat merangsang setiap orang untuk imajinatif dan melukiskan keindahan suatu benda dengan gaya masing-masing, dan sesuai dengan perasaan penciptanya.

b. Seni Tari (Seni Gerak)

Gerakan dalam seni tari adalah gerakan yang indah dan ritmis. Pada jenis tarian tertentu penari harus membawakan tarian atau gerakan yang kasar, bukan berarti hal tersebut tidak indah, namun biasanya karena tokoh yang diperankan oleh penari memang mempunyai karakter yang keras. Di dalam seni tari, irama gerak dan penghayatan merupakan hal yang tidak dapat diabaikan, sehingga dapat dikatakan bahwa seni tari merupakan perwujudan suatu macam tekanan emosi yang dituangkan dalam bentuk gerak seluruh anggota tubuh yang teratur dan berirama sesuai dengan musik pengiringnya.

\section{c. Seni Musik (Seni Suara)}

Dalam seni musik suara adalah faktor yang sangat penting dalam menentukan keberhasilan seni musik tersebut, vokal adalah faktor utama sedangkan susunan kata (syair), instrumen, dan sebagainya sangat menunjang karya seni musik tersebut. Pengertian seni musik secara sederhana adalah manifestasi dari cipta, rasa, dan karsa seseorang dalam bentuk suara dan irama yang memuaskan. Dalam hal ini indera pendengaran mempunyai tugas utama ketika seseorang akan menghayatinya.

\section{d. Seni Drama}

Seni drama dan seni tari pada dasarnya mempunyai persamaan yakni mempunyai unsur gerak. Gerak pada seni drama merupakan gerak makna atau gerak action. Sebenarnya seni drama adalah hasil dari seni sastra, rangkaian kalimat merupakan media yang utama yang menentukan kesuksesan karya seni drama.

Dalam penciptaannya, seni membutuhkan media sehingga seni tersebut berwujud dan dapat dinikmati oleh orang lain. Pengertian umum mengenai media seni adalah sesuatu yang dibutuhkan dalam pembuatan karya seni. Bahan atau media seni dapat berupa: bentuk, rupa, suara, dan gerak.

a. Bentuk dan Rupa

Pengertian bentuk dan rupa di sini adalah sesuatu yang dapat dilihat oleh indera penglihatan. Bentuk adalah garis, warna, bidang, tekstur, gelap, terang, dan ruang, sedangkan rupa adalah wujud dari karya seni tersebut. Kedua komponen tersebut sama-sama diperlukan dalam proses karya seni rupa. 
b. Suara

Seni musik, seni drama, dan seni tari mempunyai kesamaan yaitu samasama membutuhkan media suara. Namun dari ketiga jenis seni tersebut seni musiklah yang paling dominan membutuhkan media suara. Dalam seni drama dan seni tari suara hanya sebagai pengisi maupun iringan dalam mempertegas karakter yang dibawakannya.

c. Gerak

Seni yang mengutamakan media gerak adalah seni tari, baik itu berupa gerak indah maupun gerak tegas dan keras. Gerak indah dapat kita nikmati pada tarian Srimpi, Gambyong dan lain sebagainya. Sedangkan gerak keras dan tegasdapat kita temui pada tarian yang bertema perang, dan sebagainya. Selain berupa gerak, penghayatan atau penjiwaan juga mempunyai peran yang sangat penting.

Komposisi seni adalah susunan atau perimbangan dalam seni. Berhasil atau tidaknya suatu karya seni ditentukan oleh unsur-unsurnya. Sehingga susunan itu dapat membentuk ungkapan sesuai yang dikehendakinya. Antara unsur yang satu dengan unsur yang lain memiliki keterkaitan dan akan menentukan indah tidaknya suatu karya seni. Karya seni yang baik adalah yang mampu memadukan unsur-unsur seni sehingga terbentuk karya seni yang bernilai. Susunan unsur karya seni pada umumnya mencakup atau memperhatikan beberapa kaidah atau ketentuan: (1) proporsi, (2) keseimbangan; (3) harmoni; (4) irama; (5) kontras; (6) pusat perhatian; dan (7) keutuhan.

Pengertian yang paling dekat dengan istilah proporsi adalah perbandingan. Antara unsur satu dengan unsur-unsur lainnya harus ada keseimbangan. Misalnya dalam seni musik, antara suara penyanyi dengan iringan musiknya harus dibawakan secara seimbang, tidak mungkin hanya berdiri sendirisendiri. Keseimbangan (balance), adalah apabila beberapa unsur karya seni dapat memberi rasa seimbang serta memuaskan kepada kita yang melihat dan merasakannya. Dalam seni tari misalnya keseimbangan dapat dilihat dari tata rias, cara berpakaian (kostum), apakah sudah seimbang dengan tubuh penarinya. Harmoni adalah proporsi yang cocok dari hasil pengamatan. Istilah harmoni sering disejajarkan dengan istilah serasi. Harmoni dalam seni tari dapat dilihat melalui hubungan antara musik pengiring dengan irama yang ditarikan. Sebagai contoh musik pengiring yang berirama lembut dibarengi dengan irama gerak yang halus, antara musik pengiring dan irama gerak harus sesuai sehingga akan terlihat serasi.

Irama, pada awal munculnya istilah irama hanya digunakan pada seni musik, setelah seni mengalami perkembangan akhirnya perkataan irama digunakan pula untuk semua cabang seni. Dalam seni musik, ketika kita mendengarkan lagu kita akan menemukan irama yang beraneka ragam. Irama lagu pada dasarnya memiliki dua jenis, yaitu irama slow dan rock. Sedangkan pada seni rupa irama dapat timbul dari penyusunan, penempatan dan pengulangan garis, baik garis lurus maupun garis lengkung, pengulangan jenis warna, bentuk, bidang, ruang, dan sebagainya. Pengertian kontras adalah unsur karya seni satu dengan yang lainnya tampak jelas perbedaannya, bahkan berlawanan. Pada pementasan seni antara background panggung dengan bentuk pementasan harus 
sesuai. Sedangkan kontras akan tampak lebih jelas pada seni lukis. Misalnya warna hijau pada seni lukis akan kontras dengan warna merah, dan sebagainya.

Pusat perhatian, hasil karya seni terdiri dari beberapa unsur yang saling berhubungan erat, agarkarya seni tersebut dapat menarik perhatian maka pusat perhatian (center of interest) atau dominasi perlu ditempatkan pada bagian tertentu yang perlu ditonjolkan. Cara menempatkan pusat perhatian pada hasil karya seni rupa tidak mudah dilakukan. Penempatan dominasi memerlukan pertimbangan yang matang. Biasanya pada seni lukis dominasi ditempatkan dibagian tengah sehingga tepat pada sasaran mata memandang. Keutuhan, menilai karya seni harus dinilai secara utuh (totalitas) artinya harus dinilai secara keseluruhan. Menilai baik dari segi fisik (bentuk) dan dari segi non fisik (tema atau isi karya seni yang ditampilkan). Begitu pula kreativitas, teknik dan visi penciptanya. Hasil karya seni dapat mendekati sempurna apabila beberapa kaidah yang telah diketengahkan di atas menunjukkan keutuhan, artinya satu sama lain saling berhubungan dan saling mendukung.

Proses mencipta seni adalah merubah sesuatu menjadi sesuatu yang bernilai baru (Sulistyo, 2005: 92). Kegiatan mencipta di sini dalam arti luas, bisa yang berhubungan dengan seni maupun tidak. Dalam dunia seni yang dimaksud dengan mencipta adalah mewujudkan sesuatu dengan sesuatu yang sudah ada dengan nuansa baru. Proses penciptaan dalam kesenian merupakan perpaduan dari faktor internal sang pencipta sendiri dan faktor dari luar. Sementara itu Matisse berpendapat bahwa penciptaan dalam seni dimulai dari pengalaman (Sulistyo, 2005: 92). Pengalaman dapat diawali dengan segala sesuatu yang ada disekitarnya. Segala sesuatu yang kita lihat dapat menjadi ide-ide baru untuk kita ungkapkan dalam bentuk kreasi seni yang baru. Bagi seorang seniman lebih mudah baginya untuk menangkap rangsangan atau gejala yang dihadapinya. Dari gejala-gejala yang ada akan ia ciptakan sesuatu yang baru, bermakna, dan bernilai. Sedangkan munculnya daya kreativitas seorang seniman itu sendiri tidak lepas dari latihan-latihan, luasnya pengetahuan serta kerja kerasnya.

Ditinjau dari masa dan tujuan penciptaannya semua cabang seni mempunyai pada dasarnya mempunyai perkembangan yang sama. Seni muncul sejak ratusan bahkan ribuan tahun yang lalu, namun seni selalu mengalami perkembangan dari waktu dan waktu. Seni yang diciptakan pada masa lampau dapat kita sebut sebagai seni kuno atau primitif. Seni yang diciptakan pada masa pertengahan dapat kit sebut sebagai seni klasik, sedangkan seni yang diciptakan pada masa sekarang dapat kita sebut sebagai seni modern. Seni primitif, yang menjadi patokan sebuah seni dikatakan sebagai seni primitif adalah usia seni. Contoh hasil karya seni primitif adalah lukisan dinding yang terdapat di Lascoux Perancis Selatan dan di Gua Altamira Spanyol. Menurut ahli purbakala lukisan ini diciptakan lebih kurang 15.000 tahun yang lalu. Tujuan penciptaan seni pada masa itu adalah untuk keperluan upacara kepercayaan yang diselenggarakan menjelang berburu, sehingga gambar-gambar yang dilukis adalah binatangbinatang yang menjadi buruannya. Di Indonesia, hasil seni rupa yang tergolong primitif bisa berupa batu bergambar di Pasemah Sumatra.

Seni klasik, awal mulanya berasal dari kepercayaan bangsa Yunani kuno. Bentuk karya seni pada bangsa Yunani kuno adalah patung dewa-dewi yang didasari oleh idealisme, homosentris, keseimbangan, dan harmoni. Hal ini dilandasi oleh falsafah hidup bangsa Yunani pada saat itu yang menempatkan 
manusia sebagai sumber segala-galanya. Di Indonesia seni klasik ditandai dengan masuknya kebudayaan asing ke Indonesia sehingga terjadi perubahan kebudayaan bangsa Indonesia dengan bangsa Hindu. Hasil seni klasik di Indonesia sebagian besar terdapat di pulau Jawa dan Bali. Di pulau Jawa terdapat Candi Borobudur, Prambanan, Kalasan, dan sebagainya. Seni modern, pada karya seni modern aturan atau norma-norma keagamaan dan kepercayaan tidak selalu ditonjolkan. Inti pada penciptaan seni modern adalah kreativitas dan kebebasan. Penciptanya memiliki kebebasan untuk menampilkan karya yang barsifat pribadi dan orisinil. Di Indonesia seni Modern dimulai dari hasil karya seorang pelukis yang bernama Raden Saleh Syarif Bustaman, sebab dari hasil karya ini tujuan dari penciptaannya tidak terikat oleh aturan-aturan tertentu, melainkan hanya mementingkan daya kreativitasnya. Pada seni modern kreativitas lebih diminati dan bernilai daripada karya seni yang melambangkan norma keagamaan maupun kepercayaan.

\section{Reog Ponorogo}

Reog adalah salah satu keseniaan terkenal dari Indonesia yang sampai sekarang masih aktif dan dikenal dari seluruh masyarakat Indonesia bahkan wisatawan mancanegara. Menurut Sudirman (2009: 44) asal mula terbentuknya Reog berawal dari salah satu Punggawa dari kerajaan Majapahit yang mengasingkan diri dan membuat suatu tempat yang diberi nama kademangan Suru Kubeng, dengan gelar Ki Demang Kutu atau Ki Suryo Alam. Dengan berdirinya Kademangan Suru Kubeng, maka lama kelamaan banyak pengikutnya yang menjadi murid dari Ki Ageng Kutu, untuk berlatih kanoragan. Meskipun telah mengasingkan diri dari kerajaan Majapahit tetapi Ki Surya Alam tetap mengikuti perkembangan di kerajaan Majapahit. Dalam pengamatannya ki Demang Kutu tidak sependapat dengan apa yang dilakukan raja, karena setiap tindakan dan keputusan besar yang diambil kerajaan selalu dipengaruhi sang permaisuri. Raja tidak memiliki pendirian yang tegas dalam mengambil keputusan dan tergantung kepada permaisuri raja, posisi raja sangat lemah dan tidak memiliki prinsip yang kuat dan tidak mandiri.

Demikian juga yang terjadi pada barisan prajurit kerajaan Majapahit, bala tentara sangat lemah, tidak memiliki keberanian berperang untuk menyerang. Ketangguhan prajurit Majapahit tidak seperti ketika Ki Surya Alam masih menjadi Tamtama di Majapahit, yang gagah berani dan selalu siap bertempur di mana dan kapan saja dibutuhkan kerajaan. Tidak demikian halnya sekarang, prajurit Majapahit lemah dan tidak pemberani seperti pada masanya dulu. Ki Demang Kutu sangat kecewa dengan keadaan kerajaan yang demikian itu, maka dia memprotes dengan membuat sindiran terhadap raja dan prajurit Majapahit. Wujud dari ketidakpuasannya dituangkan dalam bentuk pertunjukan rakyat dengan menciptakan sebuah topeng kepala harimau sebagai simbol seorang raja dan di atasnya diberi simbol burung merak yang sedang membentangkan sayapsayap indahnya sebagai simbol dari sang permaisuri raja.

Bentuk permainan itu dinamakan barongan, yang kemudian terkenal dengan sebutan reog. Yaitu lambang atau simbol bahwa sang raja dalam menjalankan pemerintahannya disetir oleh sang permaisuri. Untuk menyindir prajurit Majapahit, Ki Demang Surya Alam menciptakan tarian yang dilakukan oleh anak muda yang tampan dengan menunggang kuda berpakaian keprajuritan tetapi baju yang digunakan adalah kebaya perempuan dengan rambut panjang dan 
dirias cantik seperti seorang perempuan, dengan gerakan tarian yang feminin dan lemah gemulai seperti wanita yang sedang menari. Hal ini sangat ironis sekali dengan jiwa seorang prajurit yang seharusnya tegas, sigap, dan penuh semangat. Dalam pertunjukannya, permainan ini disebut barongan dengan diiringi oleh penabuh beberapa bende, ketipung, kendang, dan bunyi-bunyian yang mengeluarkan suara gemuruh, yang jika dibunyikan akan mengundang banyak orang untuk datang menyaksikan tontonan ini. Setiap mengadakan pertunjukan tontonan ini akan banyak disaksikan masyarakat yang ingin melihat pertunjukan baru yang diciptakan oleh Ki Demang Kutu. Merasa banyak yang menyaksikan akan simbol kritikannya terhadap Majapahit, maka timbul kekhawatiran dari Ki Demang. Maka dikumpulkanlah para pengikut-pengikutnya untuk waspada dan berjaga-jaga terhadap kemungkinan jika kerajaan Majapahit marah dan menyerang Kademangan Kutu.

Guna mengantisipasi kemungkinan tersebut, para pengikutnya dilatih olah kanoragan, yaitu ilmu beladiri dan berperang seperti yang dia miliki ketika masih menjadi prajurit pilihan di Majapahit. Yang tua dikelompokkan dengan yang tua untuk diajarkan ilmu kadigdayan dari dalam, agar memiliki kesaktian luar dalam yang tinggi. Sedangkan yang muda dikelompokkan dengan yang muda untuk berlatih adu kekuatan luar, agar kebal terhadap senjata apapun. Ki Demang memang orang yang kuat dan sakti terbukti dengan ajaran yang diberikan kepada semua murid dan pengikutnya. Untuk melengkapi kesiapan para murid dan pengikutnya mereka dibekali dengan kolor, yaitu seutas tali pengikat celana yang diikatkan dipinggang menyerupai sabuk. Kolor ini dapat digunakan sebagai alat dan senjata ketika menghadapi musuh dalam suatu pertempuran, sehingga selain ada kekuatan badan dan tenaga dalam, dapat pula menggunakan kolor sebagai senjata andalan pengikut dari Ki Demang Kutu. Inilah awal mula munculnya Reog Ponorogo. Reog Ponorogo dimainkan oleh beberapa orang penari. Masingmasing penari membawakan tarian sesuai dengan karakter tokoh yang diperankannya. Tokoh dalam Reog Ponorogo ada lima, yaitu: (1) Singo Barong; (2) Klono Sewandono; (3) Bujangganong; (4) Jatil atau Gemblak; dan (5) Warok.

\section{Keragaman Suku Bangsa dan Budaya}

Keragaman suku bangsa dan budaya adalah berbagai macam suku bangsa dan budaya yang ada di Indonesia yang menyebabkan negara kita kaya akan kebudayaan, kesenian, adat istiadat, bahasa daerah, dan sebagainya. Masyarakat Indonesia terdiri dari beragam suku bangsa. Banyaknya jumlah pulau menjadi kekayaan bangsa Indonesia sehingga masyarakat Indonesia sangat beragam. Tiap suku bangsa memiliki adat istiadat dan budaya sendiri. Budaya dan adat istiadat daerah dapat kita jumpai dalam kehidupan sehari-hari maupun dalam acara-acara tertentu. Materi pembelajaran IPS Kelas IV Semester I seperti pada Tabel 1.

\section{Tabel 1 Materi Penelitian Matapelajaran IPS Kelas IV Semester I}

\begin{tabular}{|c|c|c|}
\hline Standar Kompetensi & Kompetensi Dasar & Materi \\
\hline $\begin{array}{l}\text { 1. Memahami sejarah, } \\
\text { kenampakan alam dan } \\
\text { keragaman suku bangsa } \\
\text { di lingkungan kabupaten / } \\
\text { kota dan provinsi }\end{array}$ & $\begin{array}{ll}1.4 & \text { Menghargai } \\
& \text { keragaman suku } \\
\text { bangsa dan budaya } \\
\text { setempat (kabupaten / } \\
\text { kota, provinsi) }\end{array}$ & $\begin{array}{l}\text { Keragaman suku bangsa } \\
\text { dan budaya setempat }\end{array}$ \\
\hline
\end{tabular}


Nilai adalah ukuran yang sangat penting dalam kehidupan manusia, nilai merupakan pedoman bagi setiap tingkah laku manusia sebagai makhluk sosial. Kebudayaan maupun kesenian mengandung nilai-nilai yang sangat penting bagi kehidupan masyarakat. Kenyataan yang nampak sekarang adalah kurangnya kesadaran generasi muda akan pentingnya nilai-nilai dari kebudayaan dan kesenian setempat, sehingga sangat disayangkan jika nilai tersebut tidak dapat dijadikan generasi muda sebagai bekal bagi kehidupannya. Salah satunya adalah nilai dalam kesenian reog Ponorogo, nilai-nilai yang terdapat dalam kesenian reog Ponorogo perlu digali agar dapat diimplementasikan ke dalam materi pelajaran.

Guru sebagai pelaku pendidikan dapat mengembangkan dan menanamkan nilai-nilai tersebut kepada siswa dengan cara mengimplementasikannya dengan materi pelajaran yang sesuai. Salah satunya adalah implementasi pada materi keragaman suku bangsa dan budaya, matapelajaran IPS kelas IV Sekolah Dasar. Diharapkan dari adanya implementasi nilai-nilai dalam kesenian Reog Ponorogo terhadap materi keragaman suku bangsa dan budaya, siswa dapat menerapkan nilai-nilai tersebut dalam kehidupannya sehari-hari, serta dapat menjadi bekal maupun sebagai filter seiring dengan banyaknya kebudayaan asing yang masuk di Indonesia.

\section{METODE PENELITIAN}

\section{Pendekatan dan Jenis Penelitian}

Pendekatan yang digunakan dalam penelitian ini adalah deskriptif kualitatif. Menurut Noor (2011: 34) penelitian deskriptif adalah penelitian yang berusaha mendeskripsikan suatu gejala, peristiwa, kejadian yang terjadi saat sekarang. Penelitian deskriptif memusatkan perhatian pada masalah aktual sebagaimana adanya pada saat penelitian berlangsung. Melalui penelitian deskriptif, peneliti berusaha mendeskripsikan peristiwa dan kejadian yang menjadi pusat perhatian tanpa memberikan perlakuan khusus terhadap peristiwa tersebut. Langkah kerja untuk mendeskripsikan suatu objek, fenomena, atau suatu setting sosial terangkum dalam suatu tulisan yang berbentuk naratif. Dalam laporan penelitian kualitatif berisi kutipan-kutipan dari data atau fakta yang diungkap di lapangan untuk memberikan ilustrasi yang utuh dan untuk memberi dukungan terhadap apa yang disajikan.

Penelitian kualitatif adalah penelitian yang menekankan pada quality atau hal yang terpenting dari sifat suatu barang / jasa (Djam'an dan Aan, 2012: 22). Menurut Sutopo (2002: 111) penelitian kualitatif adalah penelitian yang studi kasusnya mengarah pada pendeskripsian secara rinci dan mendalam mengenai potret kondisi tentang apa yang sebenarnya terjadi di lapangan. Penelitian kualitatif dieksplorasi dan diperdalam dari suatu fenomena sosial atau suatu lingkungan sosial yang terdiri atas kejadian, pelaku, dan waktu. Penelitian kualitatif dilakukan untuk mengeksplor data yang tidak dapat dikuantifikasikan. Penelitian kualitatif tidak hanya sebagai upaya untuk mendeskripsikan data, tetapi hasil deskripsi tersebut berasal dari pengumpulan data yang dapat dipertanggung jawabkan.

Sehingga dapat disimpulkan bahwa penelitian kualitatif merupakan penelitian yang menghasilkan data deskriptif berupa kata-kata tertulis atau lisan dari orang-orang dan perilaku yang diamati, data tersebut dikumpulkan, diamati, 
dan dideskripsikan. Penggunaan pendekatan deskriptif kualitatif dalam penelitian ini dilakukan dengan langkah mendeskripsikan data-data yang berhubungan dengan rumusan masalah dan tujuan penelitian yang telah ditentukan. Penelitian ini berusaha mendapatkan informasi selengkap mungkin mengenai nilai-nilai yang terkandung dalam kesenian Reog Ponorogo. Pemilihan pendekatan deskriptif kualitatif ini didasarkan pada penggalian nilai-nilai yang terkandung dalam kesenian Reog Ponorogo yang digunakan untuk mengembangkan materi Keragaman Suku Bangsa dan Budaya.

Jenis penelitian yang digunakan pada penelitian ini merupakan penelitian grounded theory. Penelitian dengan pendekatan grounded theory berusaha untuk menemukan dan mengembangkan pengertian, konsep-konsep, yang akhirnya menjadi suatu teori. Dalam penelitian grounded theory desain penelitian akan berkembang selama penelitian berlangsung. Penelitian grounded theory tidak bersifat menguji atau membuktikan kebenaran suatu teori, sumber data pada penelitian ini adalah natural setting, wajar tanpa rekayasa, dan informasi diambil dari narasumber serta dokumen yang berada dalam lingkup situasi alamiah tersebut. Djam'an dan Aan (2012: 35) berpendapat bahwa pendekatan grounded theory mempunyai beberapa aspek, yaitu: (1) tujuan penelitian adalah untuk menghasilkan sebuah teori dengan menggunakan pendekatan orientasi pengembangan (construct oriented); (2) prosedur yang digunakan benar-benar didiskusikan dan sistematik; (3) peneliti menyajikan model visual, diagram berkode dari teori; dan (4) bahasa dan kesannya ilmiah dan objektif tapi berhubungan dengan topik yang sensitive secara mencolok.

Peneliti menggunakan pendekatan grounded theory karena penelitian ini bertujuan untuk menghasilkan dan mengembangkan teori berdasarkan data yang dikumpulkan. Data yang dikumpulkan dari: Dinas Kebudayaan, Pariwisata, Pemuda dan Olahraga Kabupaten Ponorogo; Sanggar Seni Sabukjanur Desa Sumoroto Kecamatan Kauman Kabupaten Ponorogo; dan seniman serta masyarakat umum, yang berupa pernyataan-pernyataan, tulisan, angka-angka, gambar, simbol-simbol maupun gerak-gerak akan dideskripsikan dan dimaknai lebih lanjut menjadi teori-teori. Teori yang dimaksud adalah nilai-nilai yang terkandung dalam kesenian Reog Ponorogo. Teori tersebut dapat dikembangkan berdasarkan data yang telah dirangkum.

\section{Sumber Data}

Data pada penelitian ini adalah kesenian Reog Ponorogo. Peneliti menggali nilai-nilai yang terdapat dalam kesenian Reog Ponorogo untuk mengembangkan materi IPS Sekolah Dasar. Materi yang akan dikembangkan dalam penelitian ini adalah Keragaman Suku Bangsa dan Budaya Setempat. Pemilihan materi ini disertai alasan bahwa dalam sebagian besar buku paket IPS Kelas IV Sekolah Dasar materi yang dibahas adalah budaya Jakarta, materi tersebut menuntut siswa untuk berpikir secara abstrak jika diajarkan pada siswa di luar daerah yang sama sekali tidak mengetahui wujud nyata dari budaya Jakarta. Hal ini tidak sesuai dengan cara berpikir anak usia sekolah dasar yang lebih ditekankan untuk berpikir secara konkret.

Subjek dalam penelitian ini adalah: Dinas Kebudayaan, Pariwisata, Pemuda dan Olahraga Kabupaten Ponorogo; Sanggar Seni Sabuk Janur Desa Sumoroto Kecamatan Kauman Kabupaten Ponorogo; dan seniman serta 
masyarakat umum. Peneliti memilih narasumber yang memiliki pengetahuan luas tentang Reog Ponorogo dan sering terlibat dalam festival reog baik sebagai pemeran dalam tari reog maupun sebagai pelaksana festival Reog Ponorogo. Sedangkan masyarakat sekitar yang tidak mengetahui sejarah reog dan tidak berkepentingan pada masing-masing tempat penelitian diprediksi tidak memiliki informasi yang akurat mengenai nilai-nilai yang terkandung dalam kesenian Reog Ponorogo, sehingga tidak sesuai untuk dijadikan sebagai narasumber atau informan dalam penelitian.

Dalam penelitian kualitatif peneliti tidak membatasi informan dengan menentukan besaran ukuran informan dengan menggunakan perhitungan statistik, karena belum tentu yang terjaring memiliki informasi yang dibutuhkan peneliti. Sehingga dalam penelitian kualitatif dilaksanakan proses seleksi untuk mendapatkan orang, situasi, kegiatan, serta dokumen lalu dipilih berdasarkan tujuan yang ingin dicapai. Data dijaring dari informan yang dipilih dengan teknik snowball sampling technique. Djam'an dan Aan $(2012,48)$ menyatakan bahwa snowball sampling merupakan salah satu bentuk judgment sampling. Cara pengambilan sampling dengan teknik ini dilakukan secara berantai, teknik penentuan sampel yang mula-mula berjumlah kecil, semakin lama semakin membesar. Dalam penelitian pertama mula-mula dipilih satu atau dua orang tetapi karena data yang didapat dirasa belum cukup maka peneliti mencari orang lain yang dapat melengkapi data yang didapat dari orang sebelumnya.

\section{Teknik Pengumpulan Data}

Pengumpulan data penelitian dilakukan secara bertahap yaitu melalui studi dokumentasi, observasi, dan wawancara. Teknik yang dilakukan secara bertahap (triangulasi) ini dipilih untuk menjamin keabsahan data yang akan diperoleh. Keabsahan data diuji dengan triangulasi teknik yaitu mengecek data kepada sumber yang sama dengan teknik yang berbeda. Pengumpulan data dilaksanakan dengan melakukan observasi, wawancara, dan studi dokumentasi. Untuk menggali nilai-nilai Reog Ponorogo, peneliti melakukan wawancara pada informan dari: Dinas Kebudayaan, Pariwisata, Pemuda dan Olahraga Kabupaten Ponorogo; Sanggar Seni Sabukjanur Desa Sumoroto Kecamatan Kauman Kabupaten Ponorogo; tokoh masyarakat (seniman) Desa Sumoroto yang menjadi pusat kesenian Reog Ponorogo serta dari masyarakat umum.

Lalu dicek dengan melakukan observasi pada Sanggar Seni Sabukjanur, serta ketika diadakan latihan Reog Ponorogo di Dinas Kebudayaan, Pariwisata, Pemuda dan Olahraga Kabupaten Ponorogo peneliti dapat melakukan observasi. Untuk melengkapi dan memperkuat data yang didapat peneliti melakukan studi dokumentasi pada Dinas Kebudayaan, Pariwisata, Pemuda dan Olahraga Kabupaten Ponorogo. Data yang dikumpulkan dari satu narasumber dan narasumber lain, maupun hasil studi dokumentasi dapat menunjukkan hasil yang berbeda. Bila ternyata diperoleh situasi yang berbeda maka peneliti akan melakukan diskusi lebih lanjut dengan sumber data untuk memastikan data yang dianggap benar dan sesuai.

\section{Prosedur Penelitian}

Langkah awal adalah peneliti masuk ke lapangan dan menentukan sumber data atau informan. Informan yang dipilih adalah yang memiliki pengetahuan luas 
tentang Reog Ponorogo dan sering terlibat dalam festival Reog baik sebagai pemeran atau penari, sebagai pelaksana, maupun sebagai penonton dalam festival Reog Ponorogo. Sedangkan anggota yang tidak mengetahui sejarah reog dan tidak memiliki berperan penting pada masing-masing tempat penelitian diprediksi tidak memiliki informasi yang akurat mengenai nilai-nilai yang terkandung dalam kesenian Reog Ponorogo, sehingga tidak sesuai untuk dijadikan sebagai narasumber. Selanjutnya peneliti melakukan kegiatan pengumpulan data dari informan yang telah ditetapkan.

\section{Teknik Keabsahan Data}

Penelitian kualitatif dapat dipercaya dan valid karena rekam jejak suatu penelitian memiliki tingkat kepercayaan tinggi, data dan sumber data satu dengan lainnya dicatat dalam suatu catatan lapangan sehingga mempermudah konfirmasi data. Pengumpulan data melalui kegiatan observasi, wawancara, dan studi dokumentasi harus dapat menghasilkan data yang valid dan dapat dipercaya. Validitas data merupakan jaminan atas kesimpulan dan tafsir makna dari penelitian. Uji validitas dapat ditentukan oleh kredibilitas temuan dan interpretasi dengan mengupayakan temuan dan penafsiran yang dilakukan sesuai dengan kondisi empirik dan disetujui oleh subjek penelitian. Untuk itu validitas data yang akan digunakan oleh peneliti adalah:

a. Triangulasi

Dalam penelitian ini, peneliti mencari data dari berbagai sumber, sehingga tidak menutup kemungkinan data dari masing-masing sumber ada yang berbeda. Peneliti perlu melakukan triangulasi, yaitu pengecekan data dari berbagai sumber. Teknik triangulasi diartikan sebagai teknik pengumpulan data yang menggabungkan berbagai teknik pengumpulan data dan sumber data yang telah ada. Triangulasi yang digunakan pada penelitian ini adalah triangulasi teknik. Triangulasi teknik adalah penggunaan beragam teknik pengungkapan data yang dilakukan pada sumber data. Teknik pengungkapan data dilakukan melalui wawancara, observasi, dan dokumentasi. Triangulasi ini dapat dilakukan oleh peneliti dengan mengumpulkan data sejenis tetapi dengan menggunakan teknik atau metode pengumpulan yang berbeda.

b. Diskusi

Diskusi ini bertujuan untuk mengkritisi hasil penelitian dan menentukan langkah pengembangan teori. Untuk lebih memantapkan jawaban yang telah dikemukakan narasumber, peneliti lebih sering melakukan diskusi dengan informan dari Dinas Pariwisata, Pemuda dan Olahraga Kabupaten Ponorogo, Sanggar Seni Sabuk Janur Desa Sumoroto Kecamatan Kauman Kabupaten Ponorogo, tokoh masyarakat (seniman) Desa Sumoroto yang menjadi pusat kesenian Reog Ponorogo dan masyarakat umum. Diskusi ini sifatnya berkelanjutan, hampir selama terjun ke lapangan dan selama penulisan. Dengan kegiatan diskusi tersebut maka data yang dikumpulkan dapat dipertanggung jawabkan.

\section{c. Memberchek}

Data harus diakui dan diterima kebenarannya oleh sumber informasi. Memberchek adalah proses pengecekan data yang diperoleh dari peneliti kepada informan. Tujuannya adalah untuk mengetahui kesesuaian data yang diberikan oleh pemberi data. Memberchek dilakukan pada subjek wawancara dengan cara 
peneliti menyampaikan temuan kepada informan. Data yang disampaikan peneliti mungkin ada yang dikurangi, ditambah, disepakati, maupun ditolak. Sebagai kelengkapan bukti kepercayaan peneliti membuat formal administrative sebagai kelengkapan administrasi penelitian. Dalam hal ini, tidak setiap sasaran penelitian mendapat memberchek. Pengakuan kebenaran data oleh pihak-pihak tertentu yang dianggap sumber informasi dari informan dinyatakan memadai dan mewakili sumber informasi dari kegiatan wawancara.

\section{Teknik Analisis Data}

Analisis data adalah proses mencari dan menyusun secara sistematis data yang diperoleh dari hasil wawancara, catatan lapangan dan dokumentasi, dengan cara mengorganisasikan data ke dalam kategori, menjabarkan ke dalam unit-unit, melakukan sintesa, menyusun ke dalam pola, memilih mana yang penting dan mana yang akan dipelajari, dan membuat kesimpulan sehingga mudah dipahami oleh diri-sendiri maupun orang lain (Sugiyono, 2010: 335). Ketepatan pemilihan teknik analisis sangat diperlukan agar pembahasan dapat dilakukan secara mendalam dan diperoleh hasil penelitian yang bermakna. Analisis data dilakukan pada saat pengumpulan data berlangsung dan setelah selesai pengumpulan data sesuai waktu yang telah ditetapkan. Pada saat wawancara, peneliti telah melakukan analisis terhadap jawaban dari informan. Bila jawaban tersebut dirasa belum lengkap maka peneliti melanjutkan pertanyaan lagi sampai tahap tertentu sampai diperoleh data yang dianggap kredibel, kegiatan tersebut dilakukan secara terus menerus sampai tuntas, sehingga data yang didapat mencapai titik jenuh (tidak ditemukan lagi informasi baru).

Analisis dalam penelitian merupakan bagian dalam proses penelitian yang sangat penting, karena dengan analisa inilah data yang ada akan nampak manfaatnya terutama dalam memecahkan masalah penelitian dan mencapai tujuan akhir penelitian (Subagyo, 2004: 104-105). Miles dan Huberman (1992) menyebutkan bahwa aktivitas analisis data terdiri atas: data reduction, data display, dan conclusion drawing/verification yang dilakukan secara interaktif dan berlangsung secara terus menerus sampai tuntas sehingga datanya mencapai jenuh. Proses analisis data yang dilakukan dalam penelitian ini menggunakan langkah-langkah seperti diilustrasikan pada Gambar 1.

\section{a. Reduksi Data (Data Reduction)}

Data yang akan dihasilkan dalam suatu penelitian sangat banyak dan beragam, oleh karena itu perlu dilakukan analisis data melalui reduksi data. Data yang diperoleh ditulis dalam bentuk laporan yang terperinci. Untuk menyusun laporan penelitian data yang telah dikumpulkan direduksi, dirangkum, dipilih halhal yang pokok, difokuskan pada hal-hal yang penting. Data hasil dari pemilahan berdasarkan konsep, tema, dan kategori tertentu akan memberikan gambaran yang lebih tajam tentang hasil pengamatan juga mempermudah peneliti untuk mencari kembali data sebagai tambahan atas data sebelumnya yang diperoleh jika diperlukan. Reduksi data merupakan komponen pertama dalam analisis yang merupakan proses seleksi, pemfokusan, penyederhanaan, dan abstraksi data dari catatan lapangan. Menurut Sugiyono (2010: 339) reduksi data merupakan proses berfikir sensitif yang memerlukan kecerdasan dan keluasan dan kedalaman wawasan yang tinggi. 


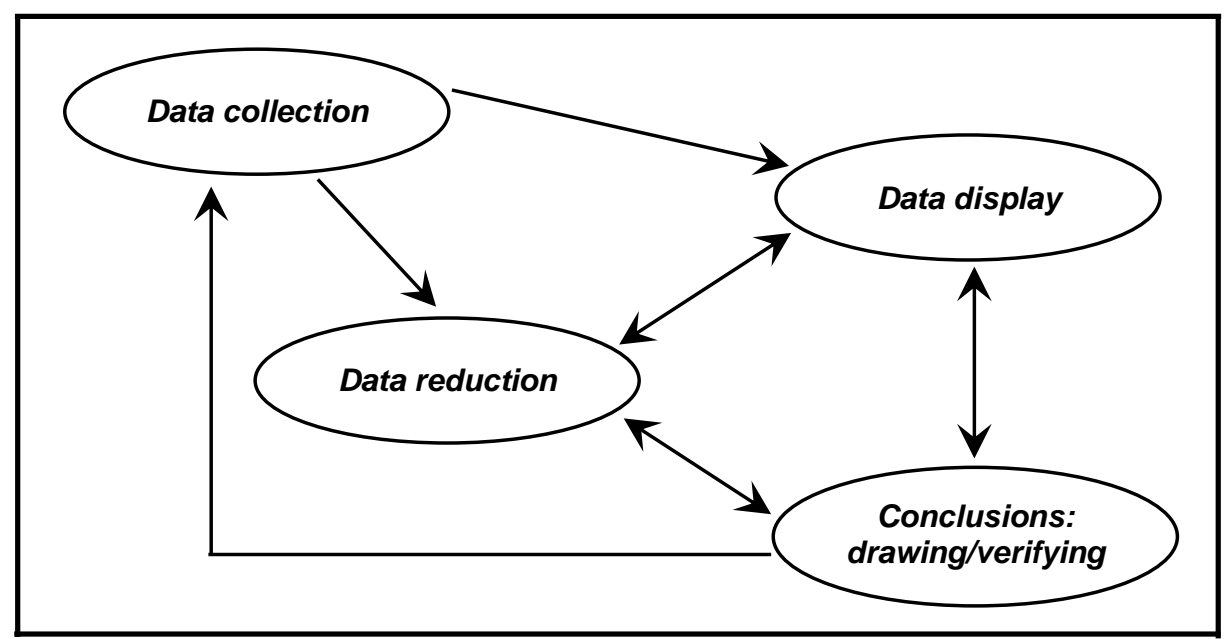

Gambar 1 Komponen dalam Analisis Data Interactive Model (Miles dan

b. Penyajian Data (Data Display)

Teknik penyajian data dalam penelitian kualitatif dapat dilakukan dalam berbagai bentuk seperti tabel, grafik, dan sejenisnya. Selain itu penyajian data juga dapat melalui kalimat, deskripsi dalam bentuk narasi yang memungkinkan simpulan penelitian dapat dilakukan dengan baik dan sistematis. Fungsi display data selain untuk memudahkan dan memahami apa yang terjadi, juga untuk merencanakan kerja selanjutnya berdasarkan apa yang telah dijadwalkan.

c. Penarikan Kesimpulan (Conclusion Drawing / Verification)

Langkah ketiga dalam analisis data adalah penarikan kesimpulan dan verifikasi. Kesimpulan awal yang dikemukakan masih bersifat sementara, dan akan berubah bila tidak ditemukan bukti-bukti yang kuat yang mendukung pada tahap pengumpulan data selanjutnya. Namun jika kesimpulan pada tahap awal didukung oleh bukti-bukti yang kuat dan konsisten saat peneliti kembali ke lapangan mengumpulkan data, maka kesimpulan yang dikemukakan merupakan kesimpulan yang kredibel. Kesimpulan dalam penelitian kualitatif dapat menjawab rumusan masalah yang telah dirumuskan sejak awal, tetapi mungkin juga tidak, karena masalah dan rumusan masalah dalam penelitian kualitatif masih bersifat sementara dan akan berkembang setelah peneliti berada di lapangan.

Kesimpulan dalam penelitian kualitatif berupa temuan baru yang sebelumnya belum pernah ada. Temuan dapat berupa deskripsi atau gambaran suatu objek yang sebelumnya masih belum jelas, bisa berupa teori atau hipotesis. Simpulan perlu diverifikasikan agar dapat dipertanggung jawabkan. Oleh karena itu kegiatan pengulangan dan perpanjangan pengamatan untuk tujuan pemantapan dan penelusuran kembali data. Verifikasi juga dapat berupa kegiatan yang dilakukan dengan lebih meningkatkan ketelitian. Verifikasi bahkan juga dapat dilakukan dengan usaha yang lebih luas yaitu dengan melakukan replikasi dalam satuan data yang lain. Pada dasarnya makna data harus diuji validitasnya supaya simpulan penelitian menjadi lebih kokoh dan lebih bisa dipercaya (Sutopo, 2002: 93). 


\section{HASIL PENELITIAN DAN PEMBAHASAN \\ 1. Kesenian Reog Ponorogo}

Kabupaten Ponorogo terletak di wilayah barat Provinsi Jawa Timur dengan luas wilayah $1.371,78 \mathrm{~km}^{2}$ yang secara administratif terbagi menjadi 21 kecamatan dan 305 kelurahan. Adapun batas-batas wilayah Kabupaten Ponorogo adalah: sebelah utara berbatasan dengan Kabupaten Madiun, Magetan, dan Nganjuk; sebelah timur berbatasan dengan Kabupaten Tulungagung dan Trenggalek; sebelah selatan berbatasan dengan Kabupaten Pacitan; sebelah barat berbatasan dengan Kabupaten Pacitan dan Wonogiri (Provinsi Jawa Tengah). Salah satu unggulan lokal dari daerah Ponorogo adalah kesenian Reog. Reog adalah kesenian yang sampai sekarang masih aktif dan dikenal oleh seluruh masyarakat Indonesia bahkan wisatawan mancanegara. Pemerintah kabupaten Ponorogo sendiri telah mendaftarkan kesenian Reog Ponorogo sebagai hak cipta milik Kabupaten Ponorogo.

Reog ada dua macam, yaitu Reog Obyog dan Reog Festival. perbedaan keduanya adalah pada garapan atau koreografinya. Reog Obyog jalan tariannya tidak tetap, dan koreografi tidak teratur. Reog Obyog biasanya hanya ditampilkan di depan rumah warga, di perempatan, dan sebagainya, sedangkan Reog Festival benar-benar didesain dengan tujuan khusus, dengan koreografi dan jalan cerita yang beraturan. Reog Festival inilah yang oleh pemerintah daerah Ponorogo dipersiapkan sebagai pertunjukan yang wajib diadakan pada waktu-waktu tertentu. Kesenian Reog Ponorogo telah mengakar kuat pada masyarakat Ponorogo, hal tersebut dibuktikan dengan banyaknya masyarakat Ponorogo yang ikut melestarikan Reog, baik sebagai pelaku Reog maupun sebagai penggemar Reog. Ketika memasuki Kabupaten Ponorogo, pada tugu perbatasan akan terlihat patung Reog Ponorogo lengkap dengan Jathil, Warok, dan gamelannya yang menunjukkan kemegahan dan keindahan Reog Ponorogo.

\section{Legenda Reog Ponorogo}

Reog adalah sebuah kesenian yang berasal dari Ponorogo Jawa Timur. Bapak Ahmad Budi Satriyo selaku sekretaris Yayasan Reog Ponorogo menyebutkan bahwa: reog sendiri adalah sebuah legenda dari bumi Ponorogo. Demikian juga Bapak Shudiq menegaskan: kalau bicara reog tidak bisa dikatakan dengan sejarah, karena ini merupakan legenda. Dari kedua pendapat di atas dapat disimpulkan bahwa Reog adalah sebuah legenda, dan belum bisa dikatakan sebagai sejarah, karena tidak terkait dengan sejarah kerajaan manapun. Berdasarkan hasil studi dokumentasi tentang legenda Reog Ponorogo, legenda reog dijelaskan sebagai berikut:

Di Kediri dahulu bertahta seorang raja yang telah cukup tua usianya. Ia mempunyai dua orang anak, yaitu seorang putri dan putranya yang laki-laki. Raja bermaksud segera menyerahkan pemerintahannya kepada putranya yang laki-laki, karena ia merasa sudah tidak mampu lagi memegang pusara kerajaan. Penyerahan ini tidak diterima dengan baik oleh putranya, sebab putra baginda itu sendiri merasa masih kurang mampu. Penolakan tersebut menimbulkan kemarahan Raja. Pada suatu malam Putra Raja tersebut meninggalkan keraton dan menuju ke Ponorogo. Di Ponorogo ia diangkat menjadi seorang patih oleh seorang raja yang 
sangat sakti mandraguna. Perjalanan panjang hingga akhirnya tiba penderitaan rakyat Ponorogo, baik dalam hal kelaparan, kematian, bahkan harimau sering berkeliaran mencari mangsa. Lalu pendeta keraton menyarankan agar Raja segera menikah dengan putri dari Raja Kediri untuk melenyapkan kesusahan tersebut. Untuk melamar Putri Kediri, raja mengutus patihnya, berbekal topeng ia menemui Raja Kediri. Namun Raja Kediri tidak percaya, jika patihnya adalah sebuah raksasa bagaimana dengan rajanya. Akhirnya Sang Patih mengaku bahwa ia adalah anak Baginda Raja itu sendiri. Hingga akhirnya Raja mengutuknya: "Engkau bukan anakku, Engkau seorang raksasa!" Karena kutukan itu akhirnya Patih menjadi seorang raksasa yang topengnya tidak dapat dilepas. Setelah kejadian itu akhirnya Raja menyesal, dan menyetujui lamaran Raja Ponorogo, dengan syarat: (1) calon temanten harus diiringi oleh seratus lima puluh ekor harimau; dan (2) perjalanan temanten dengan pengiringnya harus melalui bawah tanah. Patih menyanggupinya dan kembali ke Ponorogo. Namun sesampainya di Ponorogo, Raja tidak mengenalinya, karena beberapa pertimbangan akhirnya Raja memutuskan yang harus mempersiapkan persyaratannya adalah Patih itu sendiri, jika ia berhasil barulah ia diakui sebagai patihnya. Untuk memenuhi persyaratan itu ia memburu 150 ekor harimau dalam keadaan hidup termasuk beberapa diantaranya adalah harimau jadi-jadian, dan jalan bawah tanah dibuat oleh harimau siluman. Setelah itu berangkatlah Raja Ponorogo ke Kediri bersama para pengiringnya, dan akhirnya Putri Kediri menerima lamarannya, wujud Patih pun kembali seperti semula. Singo Barong sebagai penguasa harimau yang dibawa oleh patih tadi sangat marah sehingga terjadilah pertempuran yang akhirnya Singo Barong kalah, kepalanya diputus dan dipakai oleh para prajurit Ponorogo secara bergantian untuk menyemarakkan kemenangan mereka. Pada saat seperti itu hinggaplah burung merak di atas kepala harimau dan mengebaskan sayapnya, menandakan ia ikut berduka cita. Setelah lama menikah Sang Putri tidak juga memiliki keturunan, akhirnya ia memutuskan untuk bertapa. Sang Raja dilanda kesedihan sehingga Patih kesayangannya menghiburnya dengan menciptakan pertunjukan Reog.

Banyak pendapat mengenai legenda reog, namun semuanya memiliki inti cerita yang sama, yaitu perjalanan Raja Ponorogo untuk melamar Putri Kediri. Pada studi dokumentasi tentang sejarah Reog Ponorogo, nama tokoh tidak disebutkan secara jelas, sedangkan menurut Bapak Wisnu, menyebutkan bahwa: Prabu Klono Sewandono dari Kerajaan Bantarangin memiliki Patih Pujangga Anom (Bujangganong). Prabu Klono Sewandono ingin melamar Putri Songgolangit dari Kerajaan Kediri. Cerita yang sama juga didapat dari hasil observasi mengenai sejarah Reog Ponorogo. Berdasarkan hasil penelitian di atas, dapat disimpulkan bahwa inti cerita Reog Ponorogo sebenarnya sama yaitu perjalanan Prabu Klono Sewandono untuk melamar Putri Kediri atau Dewi 
Songgolangit, hanya saja perbedaan nama tokoh dan akhir cerita yang menyebabkan cerita reog antara satu orang dengan orang lainnya berbeda.

a. Tokoh-tokoh dalam Reog Ponorogo

Setiap cerita tentu memiliki tokoh dan permasalahan atau konflik yang dihadapi oleh para tokoh dalam alur cerita tersebut, demikian halnya pada legenda Reog Ponorogo. Reog Ponorogo menceritakan proses lamaran hingga pertarungan Raja Klono Sewandono dengan Singo Barong di alas Ludoyo. Hingga akhirnya tercipta kesenian Reog Ponorogo, sebuah kesenian yang sangat terkenal dan memiliki nilai budaya yang tinggi. Tokoh dalam Reog Ponorogo ada enam, yaitu: (1) Klono Sewandono; (2) Pujangga Anom (Pujangganong); (3) Jathilan; (4) Warok Tua; (5) Warok Muda; dan (6) Barongan. Keberadaan tokoh Reog Ponorogo tersebut diperkuat dengan penjelasan Bapak Ahmad Budi Satriyo sebagai sekretaris Yayasan Reog Ponorogo yang menjelaskan tokoh Reog Ponorogo sebagai berikut:

Tokoh Reog Ponorogo, diantaranya: Singo Barong, Bujangganong, Klono, dan Jathil, namun sekitar tahun 1987 warok mulai masuk ke dalam Reog. Reog pemiliknya adalah para warok, dulu warok hanya sebagai pendamping yang mengikuti kemana Reog pergi disetiap ada festival Reog. Dulunya warok memiliki tarian sendiri yaitu Tari Warok Kolor Sakti yang kemudian pada tahun 1987 tari tersebut digabungkan dengan Reog Ponorogo oleh seorang seniman Ponorogo yaitu almarhum Heru Subeno. Sejak saat itu warok masuk menjadi bagian dari penari Reog.

Selain itu hasil wawancara dengan Bapak Ahmad Budi Satriyo menjelaskan tokoh Reog Ponorogo sebagai berikut:

Prabu Klono Sewandono adalah raja di Kerajaan Bantarangin yang terkenal gagah, bijaksana dan sakti mandraguna. Bujangganong adalah patih yang selalu setia kepada Klono Sewandono, ia patih buruk rupa dan selalu menghibur raja. Jathil adalah kuda kembar yang digunakan Klono Sewandono ketika akan melamar Dewi Songgolangit di Kediri. Singo Barong adalah musuh Klono Sewandono yang akhirnya menjadi pengikutnya. Warok adalah pengikut prabu, yang dibekali dengan ilmu kanoragan. Kesimpulannya adalah tokoh dalam Reog ada lima, yaitu: Singo Barong, Bujangganong, Klono, Jathil, dan Warok.

b. Gemblak (Jathil) dalam Pandangan Masyarakat

Pada jaman dahulu Gemblak atau Jathil sering dipandang rendah oleh sebagian besar masyarakat. Sosok Gemblak yang dekat dengan para Warok sebagai anak asuh sekaligus sebagai pelayan para Warok, membuat Gemblak dipandang negatif oleh masyarakat luas. Untuk mempertahankan ilmunya, Warok tidak boleh berhubungan badan dengan wanita, wanita yang dimaksud di sini adalah wanita yang bukan istrinya. Namun pengertian ini disalah artikan oleh sebagian Warok, sehingga posisi Gemblak selain sebagai anak angkat juga sebagai pelayan kebutuhan biologis Warok tersebut. Ketika itu Gemblak masih dimainkan oleh anak laki-laki, sehingga pada saat itu Gemblak dipandang sebagai homoseksual sekaligus sebagai simpanan para Warok. 
Sebagai klarifikasi bagi masyarakat, bahwa sebenarnya tidak keseluruhan Gemblak mempunyai kecenderungan homoseksual, namun karena ada fakta bahwa sebagian Gemblak mempunyai kecenderungan homoseksual sehingga sebagian masyarakat memandang rendah keseluruhan Gemblak tersebut. Bapak Shudiq menegaskan bahwa: Gemblak hanya sosok anak angkat yang terpilih, realitanya tidak keseluruhan Gemblak berperilaku menyimpang. Pendapat serupa juga dikemukakan oleh Bapak Ariyo yang menyatakan bahwa: Gemblak dipandang homo akibat sebagian dari mereka berperilaku menyimpang. Seiring dengan perkembangannya Gemblak digantikan oleh wanita. Seperti yang diungkapkan oleh Bapak Ahmad Budi Satriyo sebagai sekretaris Yayasan Reog Ponorogo bahwa:

Sebenarnya memang ada Jathil atau Gemblak yang homo tetapi tidak keseluruhannya seperti itu, dan karena itulah pada perkembangannya pemain Jathil digantikan oleh perempuan. Tepatnya pada acara ulang tahun KODAM V Brawijaya dan dibutuhkan banyak pemain Jathil, sehingga kita masuk ke sekolahsekolah untuk mencari pemain Jathil yang akhirnya Jathil digantikan oleh perempuan.

Pergantian Gemblak dari laki-laki menjadi perempuan juga memiliki sisi positif dan sisi negatif. Sisi positifnya adalah pandangan homoseksual terhadap Gemblak dan Warok semakin terlupakan. Dan sisi negatifnya adalah pada Reog Obyog yang rata-rata Jathilnya menari erotis di depan Bujangganong, terlihat tidak etis. Berdasarkan wawancara dengan seniman Saudari Sari yang menyatakan: saya menganggap tarian Jathil Reog Obyog sangat erotis dan banyak Gemblak yang menyalahi aturan. Namun kembali kepada nilai dari suatu budaya, suka atau tidak suka itulah budaya yang harus dijaga dan dilestarikan sebagai budaya dari leluhur kita.

\section{c. Perkembangan Reog Ponorogo}

Seiring dengan kemajuan zaman Reog Ponorogo mengalami berbagai perkembangan. Perkembangan Reog dapat dilihat dari bentuk fisik Reog antara zaman dulu dengan zaman sekarang, seperti hasil dari studi dokumentasi perkembangan Reog Ponorogo seperti Gambar 1 dan Gambar 2.

1) Reog Zaman Dulu

Bentuk Singo Barong memanjang dan dipegang oleh dua orang, pada saat itu penari Jathil adalah laki-laki. Sosok Warok juga belum nampak pada saat itu, karena Warok pada saat itu hanya sebagai pemilik Reog yang kemana pun Reog pergi (pentas) Warok pasti akan mengikutinya di belakang. Jadi pada saat itu Warok belum masuk menjadi penari reog.

\section{2) Reog Zaman Sekarang}

Bentuk Singo Barong yang dulunya memanjang, kini berbentuk lebar dan hanya dimainkan oleh satu orang, Jathil yang dulunya laki-laki juga telah digantikan oleh perempuan. Kostum dan tata rias para penari reog lebih bagus lagi. Selain itu Warok juga sudah masuk sebagai bagian dari penari reog mulai tahun 1987-an. Pada perkembangannya reog tidak hanya dikenal oleh masyarakat Indonesia saja. 




\section{Gambar 1 Reog Sebelum Mengalami Perkembangan}

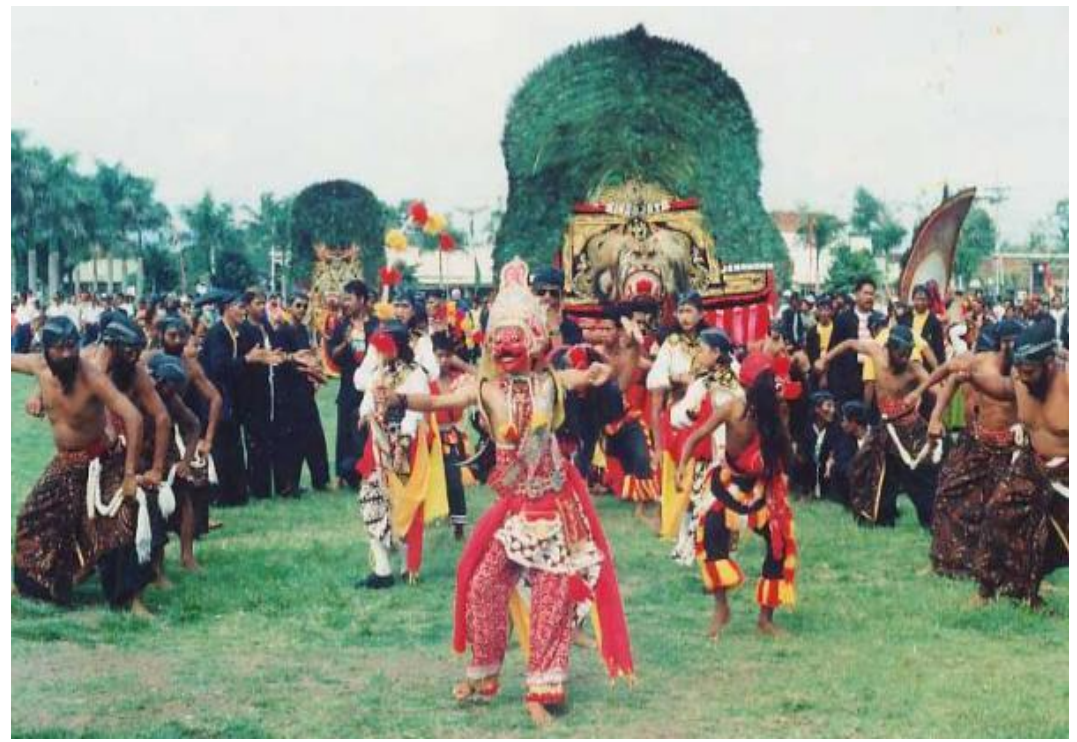

\section{Gambar 2 Reog Setelah Mengalami Perkembangan}

d. Minat Masyarakat terhadap Reog Ponorogo

Tidak salah jika ada kalimat: reog sebagai magnet dalam pengumpulan masa, seperti yang dikatakan oleh Bapak Wisnu. Minat masyarakat terhadap Reog memang sangat tinggi. Hal ini sesuai dengan hasil studi dokumentasi mengenai persentase pengunjung Festival Reog Ponorogo seperti Gambar 3. Data tersebut menunjukkan peningkatan jumlah penonton pada festival setiap tahun. Festival Reog Mini diadakan untuk menyambut hari jadi Kabupaten Ponorogo, sedangkan Festival Reog Nasional diadakan untuk menyambut tanggal 1 Muharam. Selain itu masih ada festival lainnya yang data pengunjungnya secara keseluruhan tidak terdata dari Dinas Kebudayaan, Pariwisata, Pemuda, dan Olah Raga Kabupaten Ponorogo. Namun setiap tahunnya jumlah pengunjung selalu meningkat. Selain data di atas, hasil wawancara menunjukkan masyarakat sangat menggemari festival Reog dengan berbagai alasan, salah satunya adalah saudari Rhiskyta yang menyatakan: sebagai masyarakat Ponorogo, kita harus melestarikan warisan 
budaya dan sebagai generasi muda kita harus menjunjung tinggi kebudayaan kita.

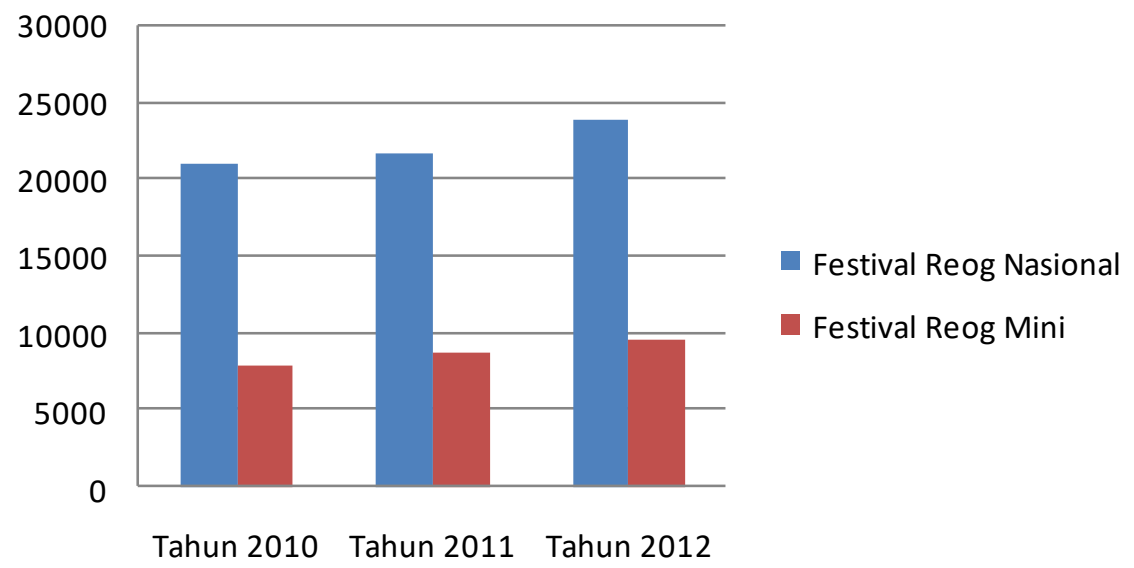

Gambar 3 Persentase Pengunjung Festival Reog Ponorogo (Sumber: Kantor Disparpora Ponorogo, 2013)

Berdasarkan pernyataan tersebut dapat diketahui besarnya semangat generasi muda untuk melestarikan budaya daerah. Hal serupa juga diungkapkan oleh saudari Sari yang mengatakan: Karena saya orang Ponorogo, saya sangat menghargai budaya daerah, salah satunya Reog, agar tidak diambil oleh negara lain. Bentuk cinta terhadap kebudayaan dapat ditunjukkan dengan semangat untuk tetap mempertahankan budaya daerah seiring dengan kemajuan zaman. Semakin masyarakat mencintai kebudayaannya maka nilai-nilai kebudayaan tersebut akan tetap terjaga dan tumbuh subur pada masyarakat tersebut. Kebudayaan tersebut akan mampu bersaing dengan budaya-budaya modern dan menjadi kebanggaan masyarakat setempat.

e. Hak Cipta Reog oleh Kabupaten Ponorogo

Reog adalah salah satu kesenian terkenal dari Indonesia yang sampai sekarang masih aktif dan dikenal oleh seluruh masyarakat Indonesia bahkan wisatawan mancanegara. Pemerintah kabupaten Ponorogo telah mendaftarkan kesenian Reog Ponorogo sebagai hak cipta milik kabupaten Ponorogo. Tercatat dengan Nomor 026377 tanggal 11 Februari 2004 dan diketahui langsung oleh Menteri Hukum dan Hak Asasi Manusia Republik Indonesia, mengingat akan keprihatinan seluruh elemen masyarakat Indonesia akan diakuinya beberapa kesenian asli bangsa Indonesia oleh bangsa lain. Hasil wawancara menunjukkan bahwa Bapak Bambang selaku Kepala Bidang Kebudayaan juga mengakui akan adanya hak cipta tersebut. Dengan adanya hak cipta tersebut diharapkan kesenian Reog Ponorogo dapat terus berkembang sebagai bagian dari kebudayaan nasional.

\section{Kebijakan Pemerintah Daerah Mengenai Reog Ponorogo dan Upaya Pelestarian Reog Ponorogo}

Pemerintah Ponorogo memiliki kebijakan agar masyarakat juga ikut membantu melestarikan kebudayaan Reog Ponorogo. Berdasarkan hasil wawancara dengan Bapak Bambang untuk melestarikan Reog Ponorogo ada kebijakan-kebijakan dalam hal mengadakan pementasan Reog Ponorogo, 
diantaranya: (1) pentas Reog Malam Purnama, yang ditampilkan adalah utusan dari kecamatan, dan masing-masing kecamatan harus mempersiapkan; (2) Festival Reog Mini, untuk jenjang SD dan SMP yang ditampilkan disetiap hari jadi Kabupaten Ponorogo; (3) Festival Reog Nasional, yang dilaksanakan setiap acara Grebek Suro; dan (4) Festival yang diadakan setiap dua tahun sekali menjelang Srebek Suro. Sudah banyak SMP yang memiliki grup Reog. Selain itu sekolahsekolah memasukkan Reog Ponorogo sebagai mulok. Dalam satu tahun saja ada beberapa festival, ini merupakan upaya daerah dalam rangka pelestarian dan regenerasi Reog Ponorogo. Hal ini juga dibuktikan dengan adanya Peraturan Bupati Ponorogo Nomor 63 Tahun 2008 Tentang Uraian Tugas dan Fungsi Dinas Kebudayaan, Pariwisata, Pemuda dan Olah Raga Kabupaten Ponorogo.

Sesuai Peraturan Bupati Ponorogo Nomor 63 Tahun 2008 Tentang Uraian Tugas dan Fungsi Dinas Kebudayaan, Pariwisata, Pemuda dan Olah Raga Kabupaten Ponorogo, tugas Bidang Kebudayaan adalah mengumpulkan bahan pembinaan, pemantauan, pelaksanaan perizinan, dan koordinasi di bidang kebudayaan. Uraian tersebut dijelaskan sebagai berikut: (1) pelaksanaan pendataan kegiatan kesenian, sejarah, nilai tradisional, museum dan kepurbakalaan; (2) pelaksanaan koordinasi dengan instansi terkait untuk memajukan kesenian serta melestarikan sejarah, nilai tradisional, museum, dan benda-benda kepurbakalaan; (3) pelaksanaan di bidang seni budaya; (4) pelaksanaan pemantauan terhadap kegiatan seni budaya; (5) penyaluran subsidi atau bantuan kepada kegiatan kesenian, sejarah, nilai tradisional, museum kepurbakalaan, serta memantau pelaksanaan dan pemanfaatannya; (6) pelaksanaan evaluasi dan pelaporan pelaksanaan tugas di bidang kebudayaan; dan (7) pelaksanaan tugas-tugas lain yang diberikan oleh kepada dinas.

Berdasarkan penjelasan di atas dapat disimpulkan Bidang Kebudayaan mempunyai wewenang untuk mendata, memajukan, serta melestarikan seluruh kegiatan kesenian, sejarah, nilai tradisional, museum dan kepurbakalaan yang ada di Kabupaten Ponorogo. Selain itu bidang kebudayaan juga mempunyai kewajiban untuk memantau kegiatan seni budaya, menyalurkan subsidi atau bantuan dan memantau pelaksanaan serta pemanfaatannya terhadap kegiatan kesenian, sejarah, nilai tradisional, museum kepurbakalaan. Tugas akhir bidang kebudayaan adalah mengevaluasi dan melaporkan pelaksanaan tugas-tugas tersebut. Dengan adanya tugas-tugas tersebut maka upaya pemerintah untuk melestarikan kesenian dan budaya dapat terarah dan berjalan lancar.

Dari hasil observasi dan wawancara, dapat diketahui bahwa tidak hanya pemerintah saja yang ingin melestarikan Reog Ponorogo, pendiri Sanggar Seni Sabukjanur yaitu Bapak Wisnu H. P. juga memilih reog sebagai tarian utama pada sanggarnya karena alasan beliau terlahir di wilayah Ponorogo sekaligus sebagai pelaku dalam kesenian Reog itu sendiri, yang secara tidak langsung spirit Reog itu selalu hadir dalam setiap penciptaan karyanya. Dari pernyataan itu dapat kita lihat seberapa besar kebanggaan beliau sebagai masyarakat Ponorogo yang ikut memiliki Reog Ponorogo itu sendiri. Masyarakat lainnya pun tidak mau kalah. Mereka menunjukkan kecintaan mereka terhadap Reog dengan cara menjadikan Reog sebagai salah satu budaya yang harus mereka cintai dan dilestarikan. Hal ini dibuktikan dengan banyaknya pengunjung pada Pagelaran Mapak Tanggal Reog Bantarangin tanggal 12 April 2013 dan keseriusan pada saat latihan Reog para penari dari Sanggar Seni Sabukjanur pada tanggal 22 April 2013. 


\section{Nilai-nilai Keunggulan Lokal Kesenian Reog Ponorogo}

Hasil penelitian yang telah dilakukan pada Dinas Kebudayaan, Pariwisata, Pemuda dan Olahraga Kabupaten Ponorogo, Sanggar Seni Sabukjanur Desa Sumoroto Kecamatan Kauman Ponorogo, serta seniman dan masyarakat umum berhasil mengumpulkan banyak data mengenai Reog Ponorogo. Reog adalah sebuah legenda yang tertuang dalam karya seni pada tangan pencipta Reog terdahulu. Karena Reog adalah sebuah legenda, maka cerita reog antara seseorang dengan orang lainnya tidak sama. Banyak sekali perbedaan pendapat antara informan satu dengan yang lainnya, namun setelah peneliti melakukan analisis data ternyata inti dari uraian pendapat tersebut sebenarnya sama. Peneliti juga membuat matriks triangulasi data, data dapat diuji kebenarannya dengan cara mengecek keabsahan data yang didapat melaui beberapa teknik, yaitu studi dokumentasi, observasi, dan wawancara. Begitu juga dengan data mengenai nilainilai Reog, pendapat satu informan dengan informan lain juga berbeda, hal tersebut dikarenakan setiap orang memiliki pandangan dan makna yang berbeda akan makna dan nilai dari setiap gerak dan rangkaian tari Reog Ponorogo.

Nilai adalah ukuran yang sangat penting dalam kehidupan manusia sebagai pedoman setiap tingkah laku manusia sebagai makhluk sosial. Kebudayaan maupun kesenian mengandung nilai-nilai yang sangat penting bagi kehidupan masyarakat. Nilai dari suatu kesenian dan kebudayaan adalah warisan bangsa yang sangat berharga. Nilai-nilai yang terkandung dalam suatu kesenian maupun kebudayaan tidak akan muncul dengan sendirinya jika kita tidak berusaha untuk mengungkapnya sejalan dengan banyaknya kebudayaan asing yang masuk ke Indonesia.

Hasil studi dokumentasi menyebutkan bahwa kesenian Reog Ponorogo dalam wujud seperti sekarang ini adalah merupakan bentuk akhir dari suatu proses panjang yang di dalamnya terkandung nilai-nilai religius dan edukatif. Nilai-nilai religius yang dimaksud adalah adanya beberapa kata dalam bahasa arab yang akhirnya menjadi bagian dari Reog, yang artinya untuk melakukan dakwah Islam dapat dilakukan melalui kesenian atau hiburan. Nilai edukatif yang dimaksudkan di sini adalah nilai yang mendidik, dalam hiburan tersebut Reog tidak hanya menyajikan hiburan, namun juga memberikan makna tersendiri bagi para penontonnya, misalnya dalam cerita tersebut ada sebuah pelajaran bagaimana seorang raja harus mengambil sikap, dan mendengarkan pendapat bawahannya.

Pandangan masyarakat satu dengan lainnya mengenai nilai-nilai reog tidak sama. Bapak Ahmad selaku sekretaris Yayasan Reog Ponorogo menyatakan bahwa: Reog Ponorogo mengandung nilai heroisme, romantisme, kesetiakawanan, kepemimpinan. Sedangkan Saudari Rhiskyta mengatakan bahwa: nilai yang terkandung dalam Reog Ponorogo adalah kedisiplinan, kerjasama, dan gotong royong. Masing-masing orang boleh saja memberikan penilaian yang berbeda, yang terpenting adalah maksud dan tujuan dari kesenian itu dapat tersampaikan dengan baik. Nilai-nilai yang didapat dari studi dokumentasi, observasi, dan wawancara dibahas sebagai berikut:

a. Romantisme

Romantisme yang dimaksud di sini adalah kisah tentang Klono Sewandono yang tergila-gila pada Dewi Songgolangit. Bapak Ahmad menjelaskan bahwa: salah satu nilai yang terkandung dalam Reog Ponorogo 
adalah romantisme. Hasil observasi mengenai nilai romantisme tersebut dijelaskan sebagai berikut: Klono Sewandono menari dengan beberapa orang Jatil secara bergantian untuk menunjukkan rasa kasmaran Klono Sewandono terhadap Dewi Songgolangit. Hal ini dikarenakan tokoh Dewi Songgolangit dalam setiap pertunjukan tidak pernah ditampilkan.

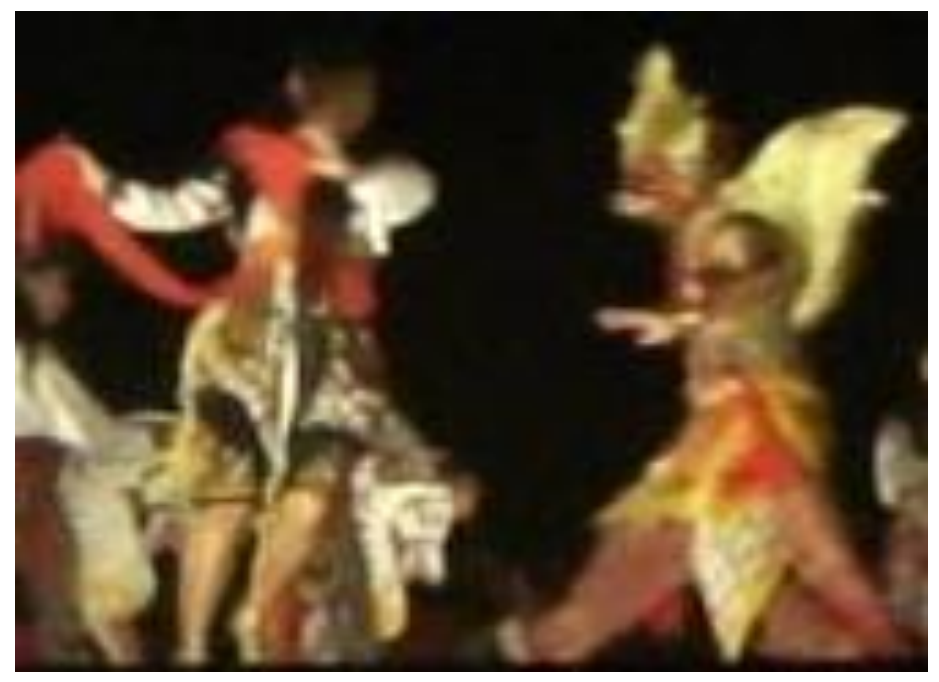

\section{Gambar 4 Klono Sewandono Menari dengan Jathil}

b. Heroisme, Perjuangan, dan Rela Berkorban

Heroisme hampir sama dengan kepahlawanan, dimana pada hasil observasi diceritakan bahwa Prabu Klono Sewandono melawan Singo Barong, pada saat perlawanan itulah nilai perjuangan dan rela berkorban muncul. Demi melanjutkan perjalanannya melamar Dewi Songgolangit ke Kediri, tanpa bantuan Bujangganong dan Jathilnya Prabu Klono Sewandono berperang sendiri melawan Singo Barong. Hasil wawancara dengan Bapak Ahmad menyatakan bahwa: nilai heroisme juga terdapat dalam kesenian Reog Ponorogo. Demikian juga dengan saudari Sari menyatakan bahwa: dalam reog terdapat nilai perjuangan dan rela berkorban. Keseluruhan nilai tersebut dapat ditemukan dalam satu adegan (rangkaian gerak tari), inilah salah satu keunikan dan keindahan Reog Ponorogo.

c. Keteladanan dan Edukatif

Nilai keteladanan yang dimaksud disini adalah sifat Klono Sewandono yang layak untuk diteladani oleh masyarakat, terutama ketika mereka menjadi seorang pemimpin. Meskipun dia seorang raja yang sakti, dia masih mau mendengarkan nasehat dari patihnya, nilai tersebut dapat dilihat bagaimana ketika dia meminta nasihat kepada Bujangganong, tetap pada posisinya bahwa dia adalah seorang raja dan tanpa menghilangkan wibawanya. Bapak Wisnu menyatakan bahwa nilai keteladanan dapat diambil dari Reog Ponorogo. Hasil dari studi dokumentasi menyebutkan bahwa salah satu nilai yang dapat diambil dari kesenian Reog Ponorogo adalah nilai edukatif. Kesenian Reog Ponorogo bersifat mendidik, mendidik bagaimana seharusnya seorang ksatria mengakui kesalahannya, seperti ketika Singo Barong ditundukkan oleh Klono Sewandono, serta ketika Klono sewandono mau memaafkan Singo Barong serta menerimanya sebagai pengiring perjalanannya ke Kediri. 
d. Kepemimpinan dan Kesetiakawanan

Sifat kepemimpinan dan kesetiakawanan harus dimiliki oleh setiap individu. Keduanya sangat penting, mengingat manusia sebagai makhluk sosial, yang tentunya tidak dapat hidup sendiri. Sifat kepemimpinan yang disertai rasa kesetiakawanan akan membuat seseorang dapat menempatkan diri, kapan ia harus bersikap layaknya pemimpin dan kapan ia harus bersikap sebagai kawan atau teman. Nilai kepemimpinan dapat ditunjukkan dengan hasil observasi ketika Klono Sewandono menuruti permintaan Singo Barong untuk menjadi pengikutnya sekaligus menjadi pengiringnya ke Kediri.

Selanjutnya Klono Sewandono memimpin pasukannya melanjutkan perjalanan ke Kediri. Pada saat Klono Sewandono akan mengajak Singo Barong ke Kediri padahal sebelumnya Singo Barong adalah musuhnya, yang pada akhirnya dia menyerah dan ingin ikut mengiring perjalanan Prabu Klono Sewandono ke Kediri, dari situlah nilai kesetiakawanan antara Klono dengan Singo Barong mulai muncul. Bapak Wisnu menyatakan bahwa: nilai kepemimpinan ada dalam Reog Ponorogo. Kedua informan lainnya juga mengatakan hal yang sama, diantaranya Bapak Ahmad dan Bapak Ariyo.

e. Kedisiplinan

Kedisiplinan adalah hal utama dalam setiap pementasan. Tanpa kedisiplinan suatu cerita tidak akan berjalan sesuai dengan skenario. Kedisiplinan akan membawa seseorang kepada kesuksesan. Dimana ketika seseorang dapat disiplin, berarti ia telah dapat menguasai dirinya sendiri dari rasa malas, dan sebagainya. Dengan kebiasaan disiplin dalam setiap hal maka seseorang telah mencoba meminimalisir kesalahan yang mungkin akan diperbuatnya. Saudari Putri menyebutkan bahwa Reog mengandung nilai kedisiplinan. Hal tersebut sesuai dengan hasil observasi ketika Jathil dan Singo Barong secara tertib mengikuti rajanya ke Kediri.

\section{f. Estetika}

Salah satu nilai yang terkandung dalam Reog Ponorogo adalah estetika. Estetika adalah kata lain dari keindahan. Keindahan pada Reog Ponorogo tidak hanya terletak pada tariannya, melainkan juga pada ide ceritanya. Keindahan tersebut yang menjadi daya pikat tersendiri bagi masyarakat, tidak hanya masyarakat Ponorogo saja. Nilai estetika tersebut muncul dalam Reog Ponorogo secara nyata, seperti yang telah dikatakan oleh saudari Rhiskyta. Selama peneliti melakukan observasi nilai estetika juga muncul dalam setiap gerakan, dimana pada setiap gerakan ada makna yang tersirat. Dengan koreografi yang tepat nilai estetika akan lebih mudah ditemukan.

g. Kebersamaan, Kerjasama dan Gotong Royong

Kebersamaan, kerjasama dan gotong royong adalah tiga hal yang selalu beriringan. Dimana ada kebersamaan disitu pasti ada kerjasama dan gotong royong. Itulah nilai dalam Reog yang seharusnya kita pelajari. Reog tidak dapat dimainkan hanya dengan seorang penari, dan tidak akan disebut Reog jika tidak ada penabuh gamelan yang megiringi tarian Reog. Reog nampak adanya kebersamaan, kerjasama, dan gotong royong para penari dan penabuh gamelan. Saudari Sari menyatakan bahwa: kebersamaan adalah salah satu nilai dari Reog Ponorogo. Pendapat kedua oleh saudari Putri menyebutkan bahwa: kerjasama dan gotong royong juga menjadi nilai dalam Reog Ponorogo. 


\section{Mengembangkan Materi Keragaman Suku Bangsa Dan Budaya Mata Pelajaran IPS Kelas IV Sekolah Dasar}

Guru memiliki kewajiban untuk mendidik peserta didik di sekolah. Berbekal dengan materi saja tentu tidak cukup. Guru perlu menanamkan karakter untuk membentuk kepribadian siswa. Penanaman karakter pada peserta didik dapat dimulai diusia dini, salah satunya adalah melalui proses pembelajaran di bangku Sekolah Dasar dengan memasukkan nilai-nilai ke dalam materi pelajaran.

a. Hubungan Nilai-nilai Keunggulan Lokal Kesenian Reog Ponorogo dengan

Materi Subbab Keragaman Suku Bangsa dan Budaya

Nilai dari suatu kesenian dan kebudayaan adalah warisan bangsa yang sangat berharga, oleh sebab itu kekayaan nilai-nilai dari suatu budaya patut digali untuk dijadikan bahan dalam pengembangan materi. Terlebih lagi untuk anak usia Sekolah Dasar guru akan lebih mudah menanamkan nilai-nilai dari suatu kebudayaan jika anak benar-benar tahu kondisi dan profil kebudayaan tersebut. Nilai tidak dapat ditanamkan hanya dengan anak berfikir secara abstrak. Reog Ponorogo mengandung nilai-nilai yang sangat beragam. Tidak semua nilai-nilai dari Reog Ponorogo dapat dijadikan sebagai bahan pengembangan materi di sekolah dasar. Untuk menjadikan nilai sebagai bahan pengembangan tentunya disesuaikan dengan usia dan pola pikir anak usia sekolah dasar, sedangkan nilai yang tidak bersifat mendidik, dan tidak sesuai dengan materi subbab keragaman suku bangsa dan budaya mata pelajaran IPS (seperti nilai romantisme, dan sebagainya) tidak digunakan untuk mengembangkan materi subbab keragaman suku bangsa dan budaya mata pelajaran IPS. Pada materi subbab keragaman suku bangsa dan budaya mata pelajaran IPS, anak akan dikenalkan dengan budaya sendiri, sehingga anak dapat berfikir secara konkret. Nilai rela berkorban, kesetiakawanan, kedisiplinan, estetika, kebersamaan, dan kerjasama sangat erat kaitannya dengan materi subbab keragaman suku bangsa dan budaya mata pelajaran IPS. Hubungan nilai-nilai keunggulan lokal kesenian Reog Ponorogo dengan materi subbab keragaman suku bangsa dan budaya dijelaskan sebagai berikut:

\section{1) Kepemimpinan}

Dalam kehidupan sehari-hari, anak tidak akan dapat lepas dari lingkungan sekitar dan teman sebaya. Anak perlu diperkenalkan dengan dunia kepemimpinan melalui pemilihan ketua kelas, wakil ketua kelas, bendahara, dan lain sebagainya. Jiwa pemimpin perlu ditanamkan pada anak sejak usia dini, dengan harapan jika mereka dewasa nanti mereka dapat menjadi pemimpin yang baik dan bertanggung jawab.

2) Estetika

Estetika dapat juga disebut dengan keindahan. Keindahan yang dimaksudkan di sini mencakup kerapian dan keseimbangan, dengan keindahan yang disajikan diharapkan orang lain dapat menikmati keindahan tersebut. Keragaman suku bangsa dan budaya merupakan salah satu keindahan yang dimiliki bangsa Indonesia. Dengan keindahan yang ada diharapkan dapat menumbuhkan rasa bangga pada siswa.

\section{3) Kerjasama}

Kerjasama adalah yang wajib dilakukan oleh kelompok atau golongan tertentu untuk mencapai tujuannya. Demikian halnya dengan bangsa Indonesia, bangsa Indonesia memiliki tujuan yang harus diwujudkan. Untuk mewujudkan 
tujuan tersebut perlu kerjasama dari seluruh masyarakat Indonesia. Selain untuk mewujudkan tujuan, kerjasama yang baik juga dapat meminimalisir terjadinya perpecahan masyarat Indonesia seiring dengan kemajuan teknologi dan beragamnya suku bangsa dan budaya di Indonesia.

Reog Ponorogo telah dikenal oleh semua kalangan, baik di daerah Ponorogo hingga ke luar negeri. Ketika anak mengetahui kondisi tersebut, akan mulai tumbuh rasa memiliki dan bangga akan budaya tersebut. Inilah awal dari penanaman nilai-nilai tersebut. Mengingat semakin banyaknya kebudayaan asing yang masuk ke Indonesia, dengan penanaman nilai tersebut akan dapat membentuk karakter yang kuat pada diri setiap peserta didik sehingga dapat menjadi filter dan bekal baginya ketika dihadapkan dengan kebudayaan yang tidak sesuai. Untuk penanaman nilai pada anak usia sekolah dasar tentu ada batasan-batasan mana yang tepat untuk dijadikan bahan pengembangan materi. Pengembangan tersebut juga harus disesuaikan dengan Standar Kompetensi dan Kompetensi Dasar.

Dengan pengembangan yang tepat penanaman nilai-nilai tersebut akan lebih mudah dipahami oleh siswa. Nilai-nilai tersebut dapat dimasukkan ke dalam materi yang sesuai yaitu materi Keragaman Suku Bangsa dan Budaya. Nilai-nilai tersebut sesuai untuk ditanamkan pada anak usia sekolah dasar dalam lingkup pembelajaran. Penanaman nilai-nilai sejak dini membantu penanaman karakter yang kuat pada diri peserta didik. Sehingga ancaman beralihnya nilai-nilai pada suatu masyarakat akibat kemajuan iptek dapat diminimalisir sedini mungkin.

\section{Pembahasan}

Nilai adalah ukuran yang sangat penting dalam kehidupan manusia yang dijadikan pedoman dalam setiap tingkah laku manusia sebagai makhluk sosial. Kebudayaan maupun kesenian mengandung nilai-nilai yang sangat penting bagi kehidupan masyarakat. Salah satunya adalah nilai yang terdapat dalam kesenian Reog. Reog adalah sendratari tradisional yang berasal dan berkembang di kabupaten Ponorogo Jawa Timur. Nilai yang terkandung dalam suatu kebudayaan khususnya Reog Ponorogo perlu digali lebih lanjut agar Reog tidak hanya menjadi sebuah tontonan, melainkan juga dapat menjadi tuntunan yang mengajarkan kebajikan hidup.

Nilai-nilai yang terkandung dalam kesenian Reog Ponorogo peneliti gunakan untuk mengembangkan materi keragaman suku bangsa dan budaya mata pelajaran IPS kelas 4 sekolah dasar. Dengan harapan nilai-nilai dari unggulan lokal tersebut dapat ditanamkan pada diri peserta didik sejak dini. Berdasarkan hasil penelitian, banyak sekali nilai-nilai yang terdapat dalam kesenian Reog Ponorogo. Nilai-nilai yang terkandung dalam kesenian Reog Ponorogo ialah:

a. Romantisme

Reog Ponorogo menceritakan tentang percintaan antara Klono Sewandono dengan Putri Kediri (Dewi Songgolangit). Klono Sewandono adalah raja yang sedang dilanda asmara dengan Dewi Songgolangit. Dari hasil penelitian, salah satu nilai yang terkandung dalam kesenian Reog Ponorogo adalah nilai romantisme. Beberapa informan mengatakan bahwa salah satu nilai yang terkandung dalam kesenian Reog Ponorogo adalah nilai romantisme, hal tersebut juga didukung oleh hasil observasi yang dilakukan peneliti pada Pagelaran Mapak 
Tanggal Reog Bantarangin. Hidayanto (2012: 2134) menyebutkan bahwa reog mengacu pada beberapa babad. Salah satunya adalah babad Kelana Sewandana. Babad Klana Sewandana konon merupakan pakem asli seni pertunjukan Reog. Mirip kisah Bandung Bondowoso dalam legenda Lara Jongrang, Babad Klono Sewandono juga berkisah tentang cinta seorang raja, Sewandono dari Kerajaan Bantarangin, yang hampir ditolak oleh Dewi Songgolangit dari Kerajaan Kediri.

Menurut Isyanti (2007: 263) suatu hari Prabu Klana Sewandono bermimpi seolah-olah berjumpa dengan seorang putri yang cantik jelita dari kerajaan Kediri bernama Putri Songgolangit. Seketika sang Prabu jatuh cinta. Ia kemudian mengutus Patih Pujangga Anom untuk melamar Putri Songggolangit. Kedua pendapat di atas secara tidak langsung telah menjelaskan bahwa Reog Ponorogo mengandung nilai romantisme, para peneliti menyebutkan bahwa Klono Sewandono jatuh cinta terhadap Putri Kediri (Dewi Songgolangit), dimana cerita tersebut sesuai dengan legenda terciptanya Reog Ponorogo yang juga tersirat dalam gerak tari Reog Ponorogo. Dengan kreativitas koreografer, kesenian Reog Ponorogo dapat diminati dan dinikmati oleh masyarakat luas.

b. Kepemimpinan

Berdasarkan hasil penelitian, nilai kepemimpinan dapat terlihat ketika Klono Sewandono memimpin pasukannya melanjutkan perjalanan ke Kediri. Selain itu Jathil, Singo Barong, dan Bujangganong selalu melakukan perintah Klono Sewandono. Dari penjelasan tersebut dapat dilihat bahwa Klono Sewandono adalah pemimpin yang berwibawa. Klana Topeng merupakan tokoh kunci yang memiliki akses terhadap seluruh pertunjukan. Klana Topeng berperan mengatur semua penari baik Warok, Jathil, Bujangganong, dan Dhadhak Merak (Maryono, 2007: 164). Klana Topeng yang dimaksud di sini adalah Klono Sewandono sabagai seorang raja yang berkuasa atas para pengikutnya. Menurut Isyanti (2007: 263) versi kedua menyebutkan bahwa kesenian reog sebenarnya merupakan sindiran kepada Raja Majapahit yang mengawini seorang putri dari Cina. Kekuasaan Raja Majapahit yang besar ternyata terkalahkan oleh kecantikan Putri Cina tersebut. Itulah sebabnya Dhadhak Merak digambarkan sebagai ksatria berkepala harimau dengan burung merak bertengger di atasnya.

Menurut versi tersebut ksatria berkepala singa adalah gambaran Raja Majapahit, sedangkan Burung Merak merupakan perumpamaan putri Cina tersebut. Raja Majapahit yang dimaksud dalam cerita ini adalah Prabu Brawijaya V mengawini seorang putri dari Kerajaan Cempa dan membuahkan anak bernama R. Kasan atau R. Patah, yang dikemudian hari menaklukkan Kerajaan Majapahit. Berdasarkan uraian tersebut disimpulkan bahwa Reog Ponorogo mengandung nilai kepemimpinan. Namun ada perbedaan karena versi ceritanya. Pada pendapat pertama, Klono Sewandono sebagai seorang raja, dialah yang mengatur semua penari, dalam hal kepemimpinan diartikan bahwa dialah yang mengatur jalannya pemerintahan, pendapat ini sesuai dengan cerita Reog versi Bantarangin. Sedangkan pendapat kedua menjelaskan pemerintahan yang dikuasai oleh wanita (permaisuri) yang akan berakhir dengan kehancuran, pendapat ini sesuai dengan cerita reog versi Ki Ageng Kutu Suryongalam yang berkaitan dengan kehancuran Kerajaan Majapahit.

c. Estetika

Nilai estetika adalah salah satu nilai yang terkandung dalam kesenian Reog Ponorogo, seperti yang diungkapkan oleh saudari Rhiskyta. Nilai estetika juga 
muncul dalam setiap gerakan, dimana pada setiap gerakan ada makna yang tersirat. Menurut Maryono (2007: 159) reog oleh pemerintah kabupaten Ponorogo diangkat menjadi kesenian khas tradisional yang menjadi aset pariwisata daerah. Reog kemudian disajikan dalam berbagai bentuk pertunjukan. Dalam beberapa festival, muncul Reog yang dikemas secara ringkas dan padat akan tetapi tetap memiliki kualitas yang tinggi. Hidayanto (2012: 2136) menyatakan bahwa seniman Reog Ponorogo lulusan sekolah-sekolah seni turut memberikan sentuhan pada perkembangan Reog Ponorogo. Mahasiswa sekolah seni memperkenalkan estetika seni panggung dan gerakan-gerakan koreografis, maka jadilah Reog Ponorogo dengan format festival seperti sekarang. Sedangkan Isyanti (2007: 262) menyebutkan bahwa kemashuran seni Reog Ponorogo memang telah mengantarkan Kabupaten Ponorogo menjadi kota yang diperhitungkan dalam peta kesenian tradisional di Indonesia.

Beberapa pendapat di atas menjelaskan keindahan Reog Ponorogo yang dapat menarik perhatian masyarakat. Keindahan Reog Ponorogo tidak hanya dapat dilihat dari rangkaian gerakannya, makna yang sangat mendalam serta legenda Reog Ponorogo tersebut mempunyai keindahan tersendiri. Dari beberapa pendapat di atas dapat disimpulkan bahwa reog sebagai kesenian tradisional telah berhasil memikat hati masyarakat luas karena keindahannya itu sendiri.

d. Kerjasama

Sebuah kelompok membutuhkan kerjasama yang kuat untuk mencapai tujuannya. Demikian juga pada sebuah grup Reog, Reog tidak dapat dimainkan hanya dengan seorang penari, dan tidak akan disebut Reog jika tidak ada penabuh gamelan yang mengiringi tarian Reog. Kerjasama berkaitan erat dengan kebersamaan, karena keduanya adalah hal yang sama-sama dibutuhkan oleh suatu kelompok. Saudari Sari menyatakan bahwa kebersamaan adalah salah satu nilai dari Reog Ponorogo. Isyanti (2007: 261) menyebutkan bahwa selain sebagai arena untuk berolah seni, kegiatan seni pertunjukan ini juga bertujuan untuk mempererat tali silaturahmi antarwarga masyarakat Ponorogo. Terlebih lagi keberadaan Reog Ponorogo ini pun sekaligus juga sebagai aset budaya yang bisa diperkenalkan kepada dunia luar, terutama guna menarik wisatawan yang ingin berkunjung ke Ponorogo. Memang reog merupakan ciri khas Kota Ponorogo sejak dahulu.

Kebersamaan antara pemain Reog Ponorogo tidak diragukan lagi. Begitu juga dengan para pemain gamelan, dengan kebersamaan itu mereka dapat mencapai tujuan, yaitu menghibur masyarakat serta menyalurkan bakat mereka. Kesenian Reog juga dapat meningkatkan kebersamaan masyarakat Ponorogo. Dengan adanya festival-festival Reog hampir seluruh masyarakat Ponorogo berkumpul, itulah sebabnya Reog dikatakan sebagai alat pengumpul masa. Nilai kerjasama dan kebersamaan inilah yang patut kita banggakan dari kesenian Reog

Ponorogo. Reog Ponorogo bukanlah satu-satunya kesenian yang wajib kita lestarikan. Sebagai generasi penerus, selain menikmati keindahannya kita juga dapat menggali nilai-nilainya sehingga kekayaan budaya bangsa tidak akan tergerus oleh kemajuan zaman.

\section{E. SIMPULAN DAN SARAN}

Berdasarkan hasil penelitian dan pembahasan, dapat disimpulkan: (1) nilai-nilai yang terkandung dalam kesenian Reog Ponorogo adalah: romantisme, kepemimpinan, estetika, dan kerjasama; dan (2)nilai-nilai yang terkandung dalam 
kesenian Reog Ponorogo dapat digunakan untuk mengembangkan mata pelajaran IPS dengan materi keragaman suku bangsa dan budaya pada kelas IV sekolah sasar. Nilai-nilai yang dapat digunakan untuk mengembangkan materi keragaman suku bangsa dan budaya pada mata pelajaran IPS kelas IV sekolah dasar adalah: kepemimpinan, estetika, dan kerjasama.

Berdasarkan kesimpulan di atas, penulis memberikan beberapa saran yang dapat berguna bagi beberapa pihak dalam meningkatkan kualitas pembelajaran IPS. Saran-saran yang disampaikan ialah bagi Depdikbud, agar memperluas khasanah pendidikan dengan cara mengimplementasikan nilai keunggulan lokal ke dalam kegiatan belajar mengajar pada lembaga-lembaga pendidikan yang bersangkutan. Bagi masyarakat pegiat kesenian untuk terus berkarya dan senantiasa melestarikan budaya bangsa. Kesenian adalah bagian dari kebudayaan bangsa yang tak ternilai harganya. Kebudayaan yang mengakar kuat pada masyarakat akan menjadi filter seiring dengan banyaknya kebudayaan asing yang masuk ke negara kita. Bagi kepala sekolah agar pengembangan potensi sekolah dapat seimbang dengan kondisi potensi lokalnya, sehingga siswa tidak akan melupakan kekayaan daerahnya masing-masing. Kepala sekolah sangat berperan penting dalam pengambilan keputusan yang berkenaan dengan peningkatan kualitas pendidikan, maupun kualitas sekolah sesuai dengan potensi masingmasing sekolah. Bagi peneliti selanjutnya untuk mengadakan penelitian sejenis dengan materi yang berbeda. Hal ini dikarenakan peneliti memprediksi masingmasing daerah memiliki unggulan lokal yang perlu digali nilai-nilainya, serta dapat digunakan untuk mengembangkan materi yang sesuai. 


\section{DAFTAR RUJUKAN}

Arikunto, S. 2005. Manajemen Penelitian. Jakarta: PT Rineka Cipta.

Asmani, J. M. 2012. Pendidikan Berbasis Keunggulan Lokal. Jogjakarta: DIVA Press.

Djam'an, A. 2012. Metode Penelitian Kualitatif. Bandung: Alfabeta.

Hartono. 1980. Reyog Ponorogo. Jakarta: Proyek Penulisan dan Penerbitan Buku / Majalah Pengetahuan Umum dan Profesi, Departemen Pendidikan dan Kebudayaan.

Hasan, I. 2004. Analisis Data Penelitian dengan Statistik. Jakarta: Bumi Aksara.

Hidayanto, A. F. 2012. Topeng Reog Ponorogo dalam Tinjauan Seni Tradisi. Jurnal Eksis, 8(1): 213-238.

Isyanti. 2007. Seni Pertunjukan Reog Ponorogo sebagai Aset Pariwisata. Jantra Jurnal Sejarah dan Budaya, II(4): 261-265.

Maryono. 2007. Reog Kemasan sebagai Aset Pariwisata Unggulan Kabupaten Ponorogo. Harmonia Jurnal Pengetahuan dan Pemikiran Seni, VIII(2): 158-168.

Miles, M. B., dan Huberman, A. M. 1992. Analisis Data Kualitatif Buku Sumber tentang Metode-Metode Baru. Terjemahan oleh Tjetjep Rohendi Rohidi. Jakarta: UI Press.

Noor, J. 2011. Metodologi Penelitian Skripsi, Tesis, Desertasi, dan Karya Ilmiah. Jakarta: Kencana.

Nurcahyo, A., Soebijantoro, Hanif, M., dan Hartono, Y. 2011. Ilmu Sosial dan Budaya Dasar. Magetan: LE-Swastika Press.

Pedoman Dasar Kesenian Reog Ponorogo Dalam Pentas Budaya Bangsa. Ponorogo: Pemkab Ponorogo.

Peraturan Bupati Ponorogo Nomor 63 Tahun 2008 Tentang Uraian Tugas dan Fungsi Dinas Kebudayaan, Pariwisata, Pemuda, dan Olah Raga Kabupaten Ponorogo. Ponorogo: Pemkab Ponorogo.

Subagyo, J. 2004. Metode Penelitian dalam Teori dan Praktek. Jakarta: Rineka Cipta.

Sudirman. 2009. Reyog, Warok, dan Gemblak. Dinamika Guru, 3(3): 34-55.

Sugiyono. 2010. Metode Penelitian Pendidikan. Bandung: Alfabeta. 
Sulistyo, E. T. 2005. Kaji Dini Pendidikan Seni. Surakarta: UNS Press.

Sutopo, H. B. 2002. Metodelogi Penelitian Kualitatif. Surakarta: Sebelas Maret University Press.

Suyatno. 2008. Pendidikan Pancasila. Solo: UNS Press.

Trianto. 2010. Model Pembelajaran Terpadu. Jakarta: Bumi Aksara. 